Boise State University

ScholarWorks

Political Science Faculty Publications and

Presentations

Department of Political Science

5-1-2017

Regions of Hierarchy and Security: US Troop Deployments, Spatial Relations, and Defense Burdens

Michael A. Allen

Boise State University

Michael E. Flynn

Kansas State University

Julie VanDusky-Allen

Boise State University 


\title{
Regions of Hierarchy and Security: US Troop Deployments, Spatial Relations, and Defense Burdens*
}

\author{
Michael A. Allen \\ Department of Political Science \\ Boise State University \\ Michael E. Flynn \\ Department of Political Science \\ Kansas State University \\ Julie VanDusky-Allen \\ Department of Political Science \\ Boise State University
}

\begin{abstract}
Recent work has begun exploring the effects of foreign military deployments on hoststate foreign policies. However, research mostly focuses on dyadic relationships between major powers and host-states, ignoring the broader regional security environment of host-states. We develop a theory of spatial hierarchies to understand how security relationships throughout the region surrounding the host-state affect hoststate foreign policy. Using data on US military deployments from 1950-2005, we show that regional security considerations condition how host-states respond to the deployment of military forces to their territory. Consequently, regional analyses are fundamental in understanding monadic and dyadic decisions about security, alliance behavior, and conflict.
\end{abstract}

Major powers have a history of deploying their military forces to project power. In spite of their importance, international relations research contains little work on the consequences of such deployments. However, scholars have begun examining a range of issues associated with US military deployments, including economic growth, trade, investment, security policy, conflict behavior, and crime (Allen and Flynn 2013; Allen, Flynn and VanDusky-Allen 2014; Biglaiser and DeRouen 2007, 2009; Brown 2013, 2014; Jones and Kane 2012; Lake 2009a; Martinez Machain and Morgan 2013). While this research area has grown, the role that such deployments play in the regional security environment remains under-explored. Accordingly, interpretations of causality in existing studies is incomplete as the regional context exerts a conditioning effect upon the relationships of interest. Fundamentally, regional security contexts should affect how states respond to the presence of foreign military forces.

Herein we examine how US military deployments affect foreign policy decisions. We build upon previous studies by incorporating regional security factors into our theoretical argument and analysis. Using data on US military deployments since 1950, we analyze how US military deployments to a host-state, as well as deployments to third-party states in the region, affect these states' defense spending decisions. Studies typically focus on the host-state's response to US troop deployments in a dyadic fashion, evaluating how US deployments affect the host- state's military spending or conflict propensity (e.g. Allen, Flynn and VanDusky-Allen 2014; Lake 2009a; Martinez Machain and Morgan 2013). This approach assumes that the effects of US military deployments on a particular state are independent of military deployments in neighboring states and the regional security environment.

\footnotetext{
* The authors would like to thank David Lake, Pat Shea, Carla Martinez Machain, Chad Clay, the editorial team at International Interactions, and two anonymous reviewers for their comments and suggestions. Replication files can be found at the International Interactions Dataverse page: http://dvn.iq.harvard.edu/dvn/dv/internationalinteractions. Questions regarding replication materials can be directed to meflynn@ksu.edu.
} 
Nevertheless, there are reasons to suspect that the effects of host-state and regional deployments are not independent (Lake 2009b). The United States deploys military forces to shape the foreign policy decisions of countries around the host-state, as much as the host-state itself. Schelling $(1966,47)$ notes that US troop deployments to West Germany and Berlin were intended to affect the decisions of the USSR. Brown $(2013,2014)$ also notes that the actions of third-party states shape the negotiations over troop deployments. Furthermore, recent work by Lake (2009a, 152-153) suggests that security and economic relations between the US and subordinate states should affect the interactions of third-party dyads. To understand how a host-state responds to military deployments by a major power, we must consider the deployments in the region surrounding the host-state.

This research provides us with greater insight into how the US-structured relationships with states conditions - and is conditioned by — similar relationships within a state's neighborhood. World politics is replete with these complex relationships, but scholars often shy away from directly modeling them. As our research shows, a range of regional security considerations affect decisions concerning something as basic as a state's defense expenditures; we cannot understand how much a state spends on its own security by viewing the state in isolation from other factors such as its regional security environment and relationships with major powers. These factors jointly condition the referent state's domestic and international decisions. The basic security concept of defense provision is as fundamental as it is illustrative: scholars ought to connect the understanding of system characteristics (polarity), major power behavior, and regional context to understand when some configurations are permissive while others are restrictive. While traditional schools of international relations assert that survival is paramount and power is instrumental to survival, our article shows that these expectations are conditional. Though we focus on defense spending, this interconnectivity is pervasive throughout world politics. Wherever we find differences in monadic, dyadic, regional, and global norms or regimes, we should expect to see these processes.

The findings of the conditional effect of troop deployments also gives scholars more information in understanding both the institutions of global hierarchy and the practical implications of US security commitments. Since the end of the Cold War, policymakers and scholars alike have debated the implications of US deployments to Western Europe (e.g. Germany), Asia (e.g. South Korea and Japan), and the Middle East (e.g. Saudi Arabia and Iraq). During the writing of this manuscript, there are active debates concerning increasing US troop commitments to the Middle East as well as the Baltic states. These deployments have implications for the neighboring region. For example, understanding Lithuania's response to a US decision to increase security commitments to that country (or to Estonia or Latvia) is easier to understand when we evaluate the regional security commitments the US has to other states in Europe. Simply evaluating Lithuanian defense expenditures purely in the US-Lithuanian dyad, or just Lithuanian expenditures relative to its neighbors, insufficiently explains Lithuania’s behavior.

More narrowly, we offer two contributions to our understanding of how US troop deployments influence host-state defense spending. First, considering the interplay between major powers' deployments to a state and deployments to neighboring third-party states yields valuable theoretical insights into states' foreign policy choices. Leaders' foreign policy decisions are not independent of the decisions made by the leaders of other states. Second, we utilize spatial measurement techniques to evaluate the theoretical implications of our argument. We find that the effect of US military deployments on host-states' defense spending is contingent upon whether third-party states in the neighboring region also host US deployments. We also find that the nature of the host-state's relationship with the US conditions how the host-state responds to US deployments.

\section{Security, Troop Deployments, and Host-State Foreign Policy}

Theoretical work concerning the tradeoffs states make between sovereignty/autonomy and security establishes the basis for previous scholarship on the relationship between military deploymentsandhoststateforeignpolicy. ${ }^{1}$ Lake(1999;2001;2009a;2009b) arguesthatstate sovereignty is a flexible concept that fluctuates temporally and spatially. States can trade away components of their sovereignty in

\footnotetext{
${ }^{1}$ Weusetheterms “sovereignty” and “autonomy”interchangeably.
} 
exchange for economic and security-based side- payments. Such tradeoffs often occur in asymmetric power relationships where a weaker state offers up some particularistic good to a more powerful state in exchange for the latter's guarantees of security. For example, in signing an alliance treaty, a weak state may cede control over its foreign policy to a more powerful state in exchange for protection (Morrow 1991).

Some scholars argue that such security-autonomy exchanges characterize US foreign pol- icy during the postwar period (Lake 1999, 2009a,b; Ikenberry 2011). The US has established security relationships with states characterized by varying degrees of hierarchical control and subordination. In exchange for ceding autonomy over their foreign policy to the US, states receive enhanced security from the US. The nature of these policy swaps leads to the formation of contractual hierarchical relationships between the US and other states. Organizations like NATO, which contains a structure that has a lower level of coercion and a higher level of equality among participants, are relatively anarchic arrangements, although the US does still try to wield some influence over NATO allies' foreign policies (Lake 2009b). Alternatively, US relations with Japan and many Latin American countries represent more hierarchical arrangements (Lake 1999, 2001). States that cede more sovereignty to the US are more subordinate states in the hierarchical relationship. Like Lake’s (1999; 2009a; 2009b) concept of sovereignty, Morrow (1991, 909) argues that a security-autonomy tradeoff characterizes alliance relationships, where a state's autonomy is a function of its capabilities and alliance relationships. Greater power disparities should produce alliances where one state cedes foreign policy autonomy in exchange for security from the more powerful state, whereas smaller power disparities may produce mutual gains in the production of security for both states.

The empirical implications of this theoretical logic concern how security ties with a major power affects the subordinate state's foreign policymaking. The more hierarchical a relation- ship, the more constrained a subordinate state's foreign policy behavior becomes. Scholars have used US troop deployments as a proxy for the magnitude of this security-autonomy trade-off. The more troops the US deploys to a state, the more security the US provides for that state, and the more sovereignty the host-state cedes to the US. Statistical analyses support the expectation that this loss of autonomy translates into smaller host-state militaries. Lake (2009a) finds that subordinate states reduce their defense burden as the size of US military deployments relative to the host-state population increases. Martinez Machain and Morgan (2013) also find that larger deployments correlate with smaller host-state militaries in terms of personnel. Lastly, US military deployments correlate with improved human rights practices by some host-state governments (Bell, Clay and Machain 2016). Building on this work, Allen, Flynn and VanDusky-Allen (2014) argue that the effect of military deployments on security tradeoffs depends on the size of the deployments, but also on power disparities and the institutional context of security relationships between the US and sub- ordinate states. They find that for many states there is a negative relationship between the size of US troop deployments and the host-state's defense burden. However, members of NATO actually increase expenditures as the US deploys more troops.

Allen, Flynn and VanDusky-Allen (2014) also examine the effects of regional US troop deployments on states' defense spending. The authors note that security relationships are often established with an eye towards the broader regional security environment surrounding a given state. They argue that deployments in the region should exert a negative effect on defense spending that is similar to the negative effect of direct deployments to the host-state itself. If states give up autonomy in exchange for the security provided by troop deployments, it follows that this dynamic should apply to states neighboring the host-state, as well as to the host-state itself. The authors argue that larger regional military deployments surrounding a state indicate that the neighbors surrounding the state are more constrained in their foreign policy behavior by the US. When a given state's neighbors are all mutually constrained by their hierarchical relations with a major power, we should expect that state to have less need of a large military. However, the results of their analysis contradict this theoretical expectation - as regional deployments correlate positively with defense spending.

In short, research has consistently found that direct deployments to a host-state yield results that are consistent with theoretical expectations (i.e. for most states, smaller militaries). However, the effects of regional military deployments contradict theoretical expectations, producing the opposite result (i.e. larger militaries). We argue that these findings reveal shortcomings in previous works. Specifically, previous 
studies have failed to consider the interaction between host-state deployments and regional deployments. In the following sections, we develop a theoretical argument that considers how the major power's relationships with third-party states in the same geographic region affect hierarchical relationships between a major power and a subordinate state.

\section{A Theory of Spatial Hierarchy}

We base our theoretical argument on previous work concerning security hierarchies by Lake (1999, $2009 a, b)$. We assume that sovereignty is fungible; states can enter into relation- ships where they agree to trade autonomy over some area in exchange for direct or indirect benefits. We argue that the combination of 1) the dyadic relationship between the US and a given state and 2) the n-adic relationship between the US and other countries in that state's region jointly explain a state's concessions in exchange for security guarantees. We refer to direct dyadic hierarchical relationships (i.e. between the US and the host-state) as "internal hierarchy" and we refer to the extended regional hierarchical relationships (i.e. between the US and neighboring states) as "external hierarchy".

As in previous studies (see Allen, Flynn and VanDusky-Allen 2014; Lake 2009a; Martinez Machain and Morgan 2013), we use troop deployments as a proxy for the extent to which the US offers security to states. We assume that by placing troops in other states, the US is creating hierarchical relationships with those host-states whereby the host-state cedes autonomy over its foreign policy in exchange for security provided by the US. We expect larger deployments to correlate with more hierarchical relationships, producing larger autonomy concessions by the host-state. Intuitively this makes senseif a state gives up autonomy in exchange for security, larger deployments should correlate with an increased likelihood that the US will become directly involved in disputes that involve the host-state. However, small deployments should also matter. Though they may not engage directly in conflicts involving the host-state, smaller deployments of military trainers and technicians can provide equipment, technology, and expertise to the host-state. Such support may come with conditions that the host-state limit or alter some policies, such as improving its human rights practices (Bell, Clay and Machain 2016). We further add that US security relationships with neighboring states condition these concessions.

For present purposes, we simplify internal and external hierarchies into two types: 1) weak or 2) strong. We assume that internal hierarchy is the strongest predictor of that state's decision to cede autonomy. However, the level of external hierarchy conditions the effect of internal hierarchy. We can think of external hierarchy as a constraint on the amount of autonomy that a state is willing to cede to the US in response to a troop deployment of a given size, as it affects the state's immediate demands for security. Considering hypothetical State A, the amount of autonomy State A cedes to the US depends on which environment State A finds itself in. Using this framework, there are four environments of influence as shown in Figure 1.

The first environment is the most basic. When both internal and external hierarchy are weak, the US should only exert a small amount of influence over State A's foreign policy. In this case, the US provides little security and State A cedes little autonomy.

Where internal hierarchy is weak but external hierarchy is strong, we expect two out- comes, which depend upon State A's relationship with the US. In the first scenario, the US has poor relations with State A. The other scenario is where State A has positive relations with the US. Although the US does not enjoy high levels of control over State A's policies 


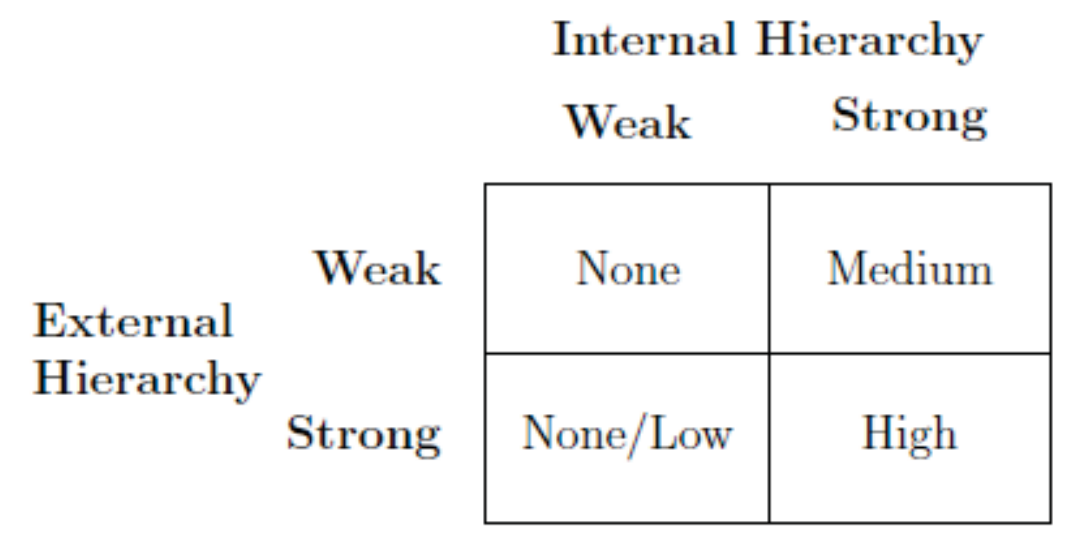

Figure 1: Basic theoretical expectations for the levels of internal and external hierarchy and level of autonomy the host-state trades. Cell contents indicate the amount of autonomy a state is expected to cede to the US.

through strong internal hierarchy, external hierarchy may have spillover effects similar to internal hierarchy. Where the US has positive relations with the referent state increasing external hierarchy may lead the referent state to cede some sovereignty to the US. Where the US has poor relations with the referent state increasing external hierarchy would likely produce no autonomy concessions.

Next, consider situations of strong internal hierarchy. Here the US is providing more security to State A and we should see State A giving up more autonomy. However, external hierarchy conditions the effect of internal hierarchy on State A's behavior. If internal hierarchy is strong and external hierarchy is weak, the US is providing security to State A, but not to states neighboring State A. While the US exerts greater control over State A's foreign policy, it lacks the ability to constrain State A's neighbors in the same way. The projection of military power into State A may actually exacerbate security dilemma dynamics between State A and its neighbors, as it necessarily alters the balance of power in the region (Brown 2013, 2014; Destradi and Gundlach 2013; Frazier and Stewart-Ingersoll 2010; Lake 2009b). Accordingly, State A should only cede a medium amount of authority when neighborhood deployments are small, since the host-state might want to maintain flexibility in dealing with potentially contentious neighbors.

Where internal and external hierarchy are both strong, State A should sacrifice more autonomy to the US. Not only is State A in a hierarchical relationship with the US, but the US has hierarchical relationships with neighboring states that similarly constrains them. Traditional types of cooperation problems, like the classic security dilemma, begin to evaporate for State A if it and third-party states are under a similar hierarchical relationship (Lake 2009a,b). The potential for war diminishes when the US has deployed increasing numbers of troops to each country. If both countries rely upon the US for security, then the US becomes the ultimate arbiter between the states. Thus, as internal and external hierarchies strengthen, the likelihood for conflict decreases.

While it is easy to theoretically conceptualize the amount of sovereignty a state cedes to the US in exchange for security, it is more difficult to quantify it. In this article, we use a state's defense burden (military spending over GDP) to measure this concept. A state's defense burden serves as an indicator of the extent to which states are channeling available resources into the pursuit of international goals. Previous studies have used this as an indicator of foreign policy autonomy, finding that when subordinate states cede foreign policy authority to the US, they reduce their defense burden and allocate resources to other policy areas in which they exercises more control (Allen, Flynn and VanDusky-Allen 2014). Hence, we use defense burdens to measure how much a state concedes sovereignty to the US.

The preceding discussion implies that the extent to which states cede sovereignty to the US and reduce their defense burdens in response to US military deployments is conditional upon regional factors. 
In general, we expect increasing internal hierarchy to correlate negatively with host-states' defense burdens. However, the level of external hierarchy moderates this effect. For any given level of internal hierarchy, we expect the negative effect to strengthen as external hierarchy increases. Accordingly, host-states in regions with small neighborhood deployments should decrease their defense burdens in exchange for US troops, but this negative effect should increase in magnitude as neighboring deployments also increase in size.

Hypothesis 1. The negative effect of host-state troop deployments on defense spending should increase in size as regional deployments increase in size.

Hypothesis 1 represents our most general expectations. However, Allen, Flynn and VanDusky-Allen (2014) have shown that NATO countries behave differently. There are important theoretical and empirical reasons to expect NATO states to behave differently. The US may use its authority in different ways in regions with high levels of internal and external hierarchy. Theoretically we might think of latent capabilities and need as two factors driving such decisions. Morrow (1991) argues that more symmetric alliances are better able to contribute meaningfully to member states' security. Additionally, allies' proximity to a major military and political rivals may also drive the US to use its authority to pro- mote greater military spending since to deter regional aggressors, as well as alleviate some of the military burden on the US itself. Since NATO states tended to be closer to the US in economic and military capabilities than most other friendly states, and because they were geographically proximate to the locus of the Cold War conflict, the defense contributions of NATO members were more likely to make meaningful contributions to US foreign policy goals.

Empirically, contributions to the collective defense have long been a concern among NATO members; previous work has also found that NATO tends to follow the US in raising and lowering defense expenditures (Palmer 1990a,b). Lake $(1999,157)$ argues that the US uses its authority over NATO states to ensure that it shares the collective burden. He further argues that the US put into place institutionalized features of the alliance, like the Annual Review, to help monitor members' efforts to meet spending goals (Lake 1999, 158). If NATO allies do not sufficiently match US contributions to the collective defense, they could have US troops removed from their territory as punishment, thereby depriving individual states of country-specific benefits (i.e. direct deployments) (Sandler 1988). Although the US could also attempt to force their non-NATO allies to increase their defense burdens, NATO states tend to be larger, more developed, and more powerful states as compared to other US allies, and are therefore better able to contribute to European defense. Lake (1999, 163-164), in reference to Pacific Rim states like Japan, the Philippines, and Micronesia, notes that "[a]lthough there were an essential part of the Pacific perimeter, they could not contribute resources beyond their bases to the American defense effort. Although Japan was expected to be less of a burden... [it] was not expected to contribute to any larger division of labor. In Europe...the expectation was quite different.”

Accordingly, because NATO states are closer to the US in terms of latent capabilities, and cluster geographically near the locus of the Cold War conflict, changes in US troop deployments within and around any given NATO state reflects broader increases or decreases in US contributions to NATO. Hence, we expect NATO allies to increase defense spending when the US deploys troops within their borders. Furthermore, we also expect this positive effect to increase as the number of regional troops increases. ${ }^{2}$

Hypothesis 2. The positive effect of host-state troop deployments on defense spending in NATO states should increase in size as regional deployments increase in size.

\footnotetext{
${ }^{2}$ Reviewers have questioned if increased defense spending by some states reflects increased offset payments to support the US military presence within their state. This is unlikely — a 2002 report from the Department of Defense indicates that the majority of cost-sharing payments made by NATO states that host US troops are indirect in nature (e.g. tax breaks). For example, in 2001 Germany paid only 0.95\% of \$861 in direct payments to the US (United States Department of Defense 2003).
} 


\section{State Responses to Regional Deployments}

Hypotheses 1 and 2 focus on how states respond to increases in internal hierarchy. But how do states respond to increases external hierarchy? As we discuss above there are two factors that should condition states' responses. First is the level of internal hierarchy. Second is the state's relationship with the US.

First, consider hypothetical state, State A, with a strong internal hierarchal relationship with the US. Regardless of the quality of its relationship with the US, this situation suggests that the US already exerts substantial control over State A's policies. When external hierarchy is low, State A may cede some autonomy over its foreign policy, but may also wish to retain some flexibility since neighboring states are not similarly subordinate to the US. That is, the high level of internal hierarchy should lead to a decrease in defense spending, but low level of external hierarchy will curb the effect. As external hierarchy strengthens, this dynamic changes. Since the US is already providing the host-state security through high levels of troop deployments, increasing deployments to the host-state's neighbors does not diminish the host-state's security vis-à-vis the other states in its neighborhood. With its neighbors increasingly subordinate to the US, the host-state should be able to lower its defense burden.

Next, consider states that have weak internal hierarchy. As we discuss above, conditions of weak internal hierarchy may produce different results depending upon the host-state's relationship with the US. Let us assume State A has weak internal hierarchy and poor relations with the US. In this case, State A may respond to increases in regional troop deployments by increasing its own military spending. State A may perceive such increases in regional troop levels as threatening due to its poor relations with the US. For example, the US has used military deployments to help contain adversarial states like Russia and China.

Now assume State A has weak internal hierarchy but has strong relations with the US. It is possible for such states to either not respond to or decrease defense spending in response to increases in external hierarchy. Although State A may have weak internal hierarchy itself, it can maintain its defense burden or safely lower it if it wants to when its neighbors are more highly subordinate to the US. In such cases, an increase in the size of regional US troop deployments may effectively increase State A's security by promoting greater stability within the region. Rather, State A enjoys positive externalities from the increased US presence in the region.

Whether a state has an alliance with the US should serve as a good indicator of its relationship with the US, and potentially condition how it responds to changes in US troop deployments in its region under conditions of weak internal hierarchy. Non-allies of the US should be more apt to respond to increases in external hierarchy by increasing defense spending. Alternatively, because they already have security guarantees from the US, allies of the US should not feel threatened by increases in regional troop deployments and should feel safer reducing military expenditures in response to such increases. Combined with our initial discussion on the effects of strong internal hierarchy, this discussion produces the following two hypotheses. ${ }^{3}$

Hypothesis 3. The positive effect of regional troop deployments on defense spending is larger in states with a smaller number of US troops than in states with a higher number of US troops.

Hypothesis 4. The positive effect of regional troop deployments on defense spending is larger in non-allied states than in allied states.

Following our discussion from the previous section, we expect NATO allies to increase their defense spending in exchange for troops. We expect this condition to hold for regional troops as well. As noted above, the proximity of NATO states suggests that increasing regional deployments are indicative of greater US contributions to NATO defense. Hence, as the number of regional troops around NATO allies increase, NATOallies shouldincreasetheir defenseburden to follow US contributions. However, this is still

\footnotetext{
${ }^{3}$ We provide an alternative test using UN ideal point scores (Bailey, Strezhnev and Voeten 2015) as opposed to alliance relationships in the supplementary appendix. The results support our expectations. See table A8 and figures A17 and A18.
} 
conditional on the number of host-state troops in the NATO state. The more security the US provide to that state through troops, the more likely that state will respond positively to regional contributions in NATO defense. We argue that this conditionality stems from the high level of internal hierarchy and the US ability to punish the host by removing troops from its territory. For NATO states with large direct deployments and small neighboring deployments, free-riding may be a greater possibility, as the US cannot credibly relocate those troops to another NATO ally. Large deployments require substantial investments to house troops and store equipment. It is difficult to punish free-riding by removing troops where there are few substitute locations capable of supporting large deployments. Accordingly, these states do not have to increase their defense spending when the US deploys more troops to their region. Alternatively, the presence of large regional deployments suggests the presence of the requisite infrastructure, thereby making it easier for the US to punish free-riding by moving troops to neighboring states. Thus, states with large direct and neighborhood deployments should be more likely increase contributions to the collective defense as the credibility of losing deployments is higher, and the likelihood of US threats are greater.

Hypothesis 5. As the number of troops within a NATO ally increases, the positive impact that regional US troop deployments around that state have on the host-state's defense spending increases.

\section{Research Design}

We base our research design on Allen, Flynn and VanDusky-Allen's (2014) analysis. We employ similar control variables and a similar estimation strategy, though we do include additional control variables to capture aspects of states' spatial/regional security relation- ships. We use a country-year unit of analysis where the dependent variable of interest is the defense burden of the observed state (the country's military spending divided by its Gross Domestic Product (GDP) for that year). We use Gleditsch (2002) data for GDP (v5.0) and the Correlates of War (COW) National Material Capabilities data to determine the defense spending of a country for a given year (Singer 1987; Sarkees and Wayman 2010) (v4.0).

Our main independent variables are US troop deployments to the host-state and a mea- sure of regional troop deployments surrounding the host-state. The first measure, $\ln$ (Troops), is the number of troops in an observed country and the second measure, In(Troops Spatial Mean), is the average number of troops in all neighboring countries. We construct both measures from Kane's (2006) data on US troop deployment for the years 1950-2005. ${ }^{4}$ We take the natural log of both variables to adjust for skew and because we have an expectation that there are diminishing returns from deploying soldiers to a country or region. ${ }^{5}$

We expect $\ln$ (Troops) and $\ln$ (Troops Spatial Mean) to jointly influence the level of a state's defense burden. To provide preliminary support for our hypotheses, Figure 2, plots our two troop deployment variables against one another in all states, non-NATO allies, NATO allies, and non-US allies, weighting the size of the circles by the size of the state's defense burden. The larger the circles, the larger the defense burden. The results provides some support for our basic hypotheses. In panels 1 and 4 , we can see that states with higher levels of regional and direct troop deployments tend to have smaller defense burdens.

${ }^{4}$ The calculation of row-standardized spatial variables $(\mu i t)$ is the following:

$$
\mu_{i t}=\sum_{k}\left[\frac{w_{i k t}}{\sum_{k}^{n} w_{i k t}} x_{k t}\right]
$$

Where ${ }_{i k t}$ is a dichotomous variable denoting that state $k$ is contiguous to referent state $i$ at time $t$ (Neumayer and Plümper 2016). Here, $w=1$ if country $k$ is within $450 \mathrm{~km}$ of referent state $i$, and $w=0$ otherwise. $x_{k t}$ represents the value of the given variable (e.g. troops) for state $k$ at time $t$. We identified neighboring countries using the Correlates of War's Direct Contiguity Data (Stinnett et al. 2002) (v3.1). We include all states falling within the five-point contiguity categories in calculating our spatial measure. See Ward and Gleditsch (2008) and Neumayer and Plümper (2016) for more on calculating spatial variables.

${ }^{5}$ We calculate the logged measured as follows: $\ln (x+1)$. 
Panel 2 is less clear, but does suggest the possibility of a similar dynamic. In panel 3 we can see that larger direct and regional troop deployments tend to positively correlate with defense spending in NATO allies, which is what we expect.

Since we expect $\ln$ (Troops) and $\ln$ (Troops Spatial Mean) to jointly affect defense spending, we construct an interactive measure between the two variables, $\ln ($ Troops $) \times \ln ($ Troops Spatial Mean) to include in our models below. This interaction allows us to examine how states respond to changes in US troop deployments within their borders given the number of US troops in their region. It also allows us to examine how states respond to changes in regional troop deployments given the number of US troops within their borders. Because our interest is in the conditioning effect of both the host-state and regional measures of troop deployments (i.e., $X$ and $Z$ jointly), we present the marginal effects of both variables below (Berry, Golder and Milton 2012).

Our models also include several factors that causally influence military spending. These variables are listed in the summary statistics table (Table 1) and are described more fully in the supplemental online appendix. Below we outline three key non-standard control variables that we include in our analysis and discussion.

First, we expand on Allen, Flynn and VanDusky-Allen (2014) by including controls for factors that US troop deployments may proxy, and to capture relevant characteristics of the state's security environment. It is possible that our focus on the spatial effect of US military deployments may proxy the effects of regional alliance relationships. The correlation between troop deployments and whether or not a state is a US ally is reasonably strong ( $r=0.51$ in the general estimation sample, Model 1$)$. Accordingly, regional deployments may similarly be capturing the US' regional alliance ties. To isolate the effect of regional US troop deployments from the effect of regional US alliance ties, we also include a variable, US Allies (Spatial Mean), that measures the proportion of states surrounding the referent state that are US allies.

We also expect other elements of the regional security environment to affect military

(1)

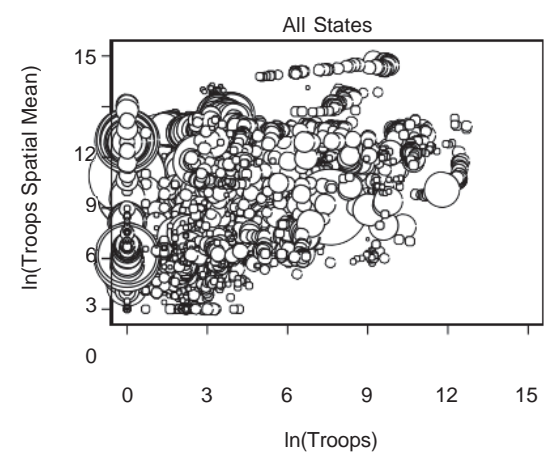

(3)

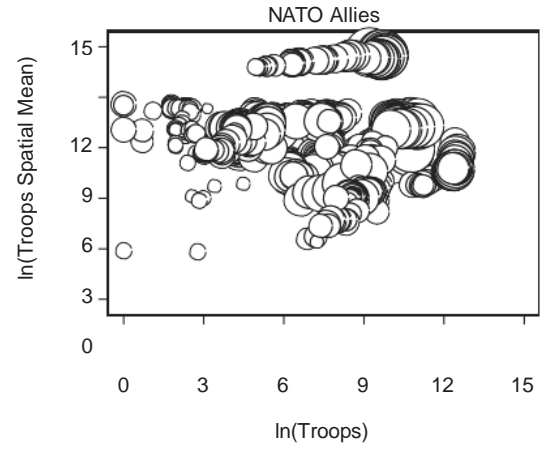

(2)

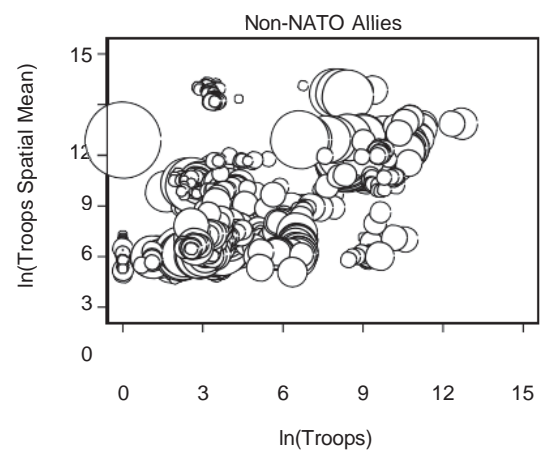

(4)

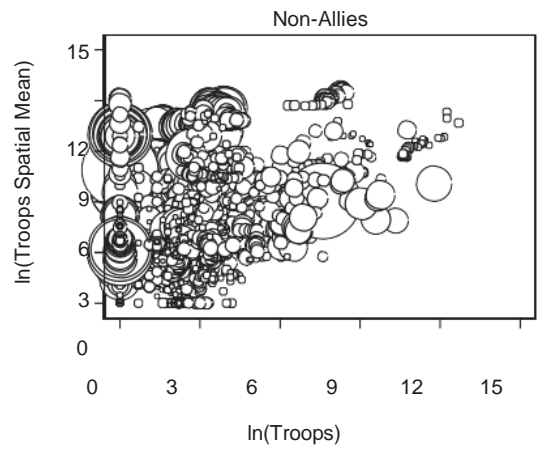

Figure 2: Scatterplots of direct and regional deployments. Symbol size weighted by defense burden size. 
spending and include two additional spatial variables to account for these dynamics. Accordingly, we include a variable, Host-State Allies (Spatial Mean), that measures the proportion of the observed state's neighbors that it is allied with. ${ }^{1}$ Lastly, the defense burdens of neigh- boring states may influence the defense burden of the observed state. Collier and Hoeffler (2002) find neighborhood defense expenditures positively affect a state's own military spending. Goldsmith (2007) also finds positive correlation between regional spending and states' defense burdens. Since we argue that military deployments affect defense spending, we must be sure that the estimated effect of regional deployments is not biased by the omission of

Table 1: Summary Statistics

\begin{tabular}{lccccc}
\hline \hline Variable Name & $\mathrm{N}$ & Mean & Std. & Min & Max \\
\hline Defense Burden & 6052 & 3.071 & 5.508 & 0.000 & 100.658 \\
ln (Troops) & 6052 & 3.272 & 2.845 & 0.000 & 12.697 \\
ln (Troops) Spatial Mean & 6052 & 5.648 & 3.212 & 0.000 & 14.665 \\
ln (Troops) × ln (Troops) Spatial Mean & 6052 & 22.449 & 27.202 & 0.000 & 141.931 \\
Host-State Allies (Spatial Mean) & 6052 & 0.404 & 0.402 & 0.000 & 1.000 \\
US Allies (Spatial Mean) & 6052 & 0.328 & 0.377 & 0.000 & 1.000 \\
Spatial Lag & 6052 & 0.036 & 0.040 & 0.000 & 0.685 \\
Polity & 6052 & -0.214 & 7.530 & -10.000 & 10.000 \\
Growth & 6052 & 3.971 & 8.228 & -67.887 & 190.764 \\
ln (Total Population) & 6052 & 9.051 & 1.498 & 4.905 & 14.063 \\
Infant Mortality Rate & 6052 & 68.005 & 51.551 & 2.300 & 284.780 \\
Interstate War & 6052 & 0.031 & 0.174 & 0.000 & 1.000 \\
Civil War & 6052 & 0.105 & 0.306 & 0.000 & 1.000 \\
MIDs & 6052 & 0.647 & 1.107 & 0.000 & 18.667 \\
Threat Environment & 6052 & 0.315 & 0.218 & 0.000 & 0.730 \\
\#Border States & 6052 & 3.724 & 2.240 & 1.000 & 20.000 \\
\hline
\end{tabular}

neighboring military expenditures, which those deployments should also affect. We include a Spatial Lag variable to capture the average level of neighboring states' defense burdens.

These spatial variables give us additional explanatory power on how regional troop deployments independently affect defense spending behavior. We derive these measures using alliance data from the Alliance Treaty Obligations and Provisions (ATOP) project (Leeds et al. 2002) and contiguity data from the Correlates of War's Direct Contiguity Data (Stinnett et al. 2002) (v3.0).

We run four different models using different sub-samples, since we have different theoretical expectations for different types of states. To capture our most general expectations we first run a pooled model that includes all states. Next, we divide the sample into three sub-samples: 1) Non-NATO allies of the US, 2) NATO members, and 3) States that have no alliances ties with the US.

We estimate our models using a Prais-Winsten regression with panel-corrected standard errors and an AR(1) serial correlation structure. ${ }^{2}$ We lag all independent variables in the model one time period $(t-$ 1 ), except for war, civil war, the number of border states, and the moving average of MIDs. Table 1 presents the summary statistics for all variables included in the models. ${ }^{3}$

\footnotetext{
${ }^{1}$ We limit alliances to offense or defense pacts. The procedure used to calculate these spatial measures is the same as that described in footnote 4.

${ }^{2}$ Wooldridge's (2010) test of serial correlation in indicates the presence of serial correlation in all four sub-samples, yielding $p$ $\leq .05$ in each case. Visual inspection of the residuals also warrants correcting for serial correlation.

${ }^{3}$ Allen, Flynn and VanDusky-Allen (2014) address the possible endogenous relationship between troop deployments and defense spending and find that the effect of troop deployments is consistent under alternative models designed to account for this possibility.
} 


\section{Results}

Table 2 displays the results of the four empirical models. Because we expect $\ln$ (Troops) and $\ln$ (Troops Spatial Mean) each to exert an effect that is conditional upon the other variable, we use marginal effects graphs to interpret their combined interactive effect on Defense Burden. First we examine the effect of $\ln$ (Troops) on Defense Burden across different levels of regional deployment size, displayed in Figure 3. Each panel number in Figure 3 corresponds to the matching model in Table 2.

The results generally support Hypothesis 1. First, according to Panel 1 (all countries), when there are few US troops in the region surrounding a host-state (i.e. external hierarchy is weak), increasing US troop deployments to the host-state (i.e. increasing internal hierarchy) does not have a noticeable effect on the defense spending of that state. ${ }^{4}$ However, as the average size of the regional deployments surrounding the host-state increases, US troop deployments to the host-state begin to negatively affect defense spending of that state. The marginal effect shown in Panel 1 of Figure 3 indicates that states reduce their defense burdens in exchange for US troops. At the higher end of regional troop deployments, as the number

Table 2: US Troop Deployments and Host-State Defense Burdens

\begin{tabular}{|c|c|c|c|c|c|c|c|c|}
\hline \multirow[b]{2}{*}{$\ln$ (Troops) } & \multicolumn{2}{|c|}{$\begin{array}{c}(1) \\
\text { All States }\end{array}$} & \multicolumn{2}{|c|}{ (2) } & \multicolumn{2}{|c|}{$\begin{array}{c}(3) \\
\text { NATO }\end{array}$} & \multicolumn{2}{|c|}{$\begin{array}{l}(4) \\
\text { Non- }\end{array}$} \\
\hline & 0.032 & $(0.098)$ & 0.022 & $(0.046)$ & -0.161 & $(0.129)$ & -0.148 & $(0.159)$ \\
\hline ln (Troops Spatial Mean) & $0.565^{* * *}$ & $(0.079)$ & 0.063 & $(0.044)$ & -0.099 & $(0.095)$ & $0.667^{* * *}$ & $(0.096)$ \\
\hline Troops $\times$ Troops Spatial Mean & $-0.040^{* * *}$ & $(0.012)$ & -0.004 & $(0.008)$ & $0.027^{* *}$ & $(0.013)$ & -0.032 & $(0.021)$ \\
\hline Spatial Lag & $17.957^{* * *}$ & $(2.901)$ & $0.894^{*}$ & $(0.534)$ & $9.444^{* * *}$ & (3.019) & $25.860^{* * *}$ & (3.779) \\
\hline Host-State Allies (Spatial & $2.025^{* * *}$ & $(0.441)$ & -0.381 & $(0.435)$ & $0.596^{*}$ & $(0.338)$ & $2.292^{* * *}$ & $(0.523)$ \\
\hline US Allies (Spatial Mean) & $-1.965^{* * *}$ & $(0.476)$ & -0.027 & $(0.558)$ & $0.591^{* *}$ & $(0.290)$ & $-2.263^{* * *}$ & $(0.841)$ \\
\hline Polity & $-0.091^{* * *}$ & $(0.013)$ & $-0.018^{* * *}$ & $(0.006)$ & $-0.031^{*}$ & $(0.016)$ & $-0.126^{* * *}$ & $(0.018)$ \\
\hline Growth & -0.005 & $(0.007)$ & -0.001 & $(0.003)$ & 0.000 & $(0.005)$ & -0.004 & $(0.008)$ \\
\hline ln (Population) & -0.071 & $(0.139)$ & -0.081 & $(0.098)$ & $0.321^{* * *}$ & $(0.072)$ & -0.053 & $(0.161)$ \\
\hline Infant Mortality Rate & $-0.007^{*}$ & $(0.004)$ & -0.001 & $(0.001)$ & $0.007^{*}$ & $(0.003)$ & $-0.009^{*}$ & $(0.005)$ \\
\hline Interstate War & $1.394^{* * *}$ & $(0.319)$ & $0.259^{*}$ & $(0.143)$ & 0.166 & $(0.104)$ & $2.266^{* * *}$ & $(0.526)$ \\
\hline Civil War & $0.681^{* *}$ & $(0.287)$ & 0.000 & $(0.075)$ & 0.101 & $(0.115)$ & $0.856^{* *}$ & $(0.372)$ \\
\hline MIDs & 0.131 & $(0.127)$ & $0.134^{*}$ & $(0.073)$ & 0.012 & $(0.053)$ & 0.172 & $(0.160)$ \\
\hline Threat Environment & $-3.301^{* * *}$ & $(0.834)$ & $-1.027^{*}$ & $(0.532)$ & -0.949 & $(0.650)$ & $-2.913^{* *}$ & $(1.297)$ \\
\hline \# Border States & $0.140^{*}$ & $(0.080)$ & 0.041 & $(0.049)$ & -0.016 & $(0.034)$ & 0.074 & $(0.101)$ \\
\hline Constant & 1.644 & (1.379) & $2.411^{* *}$ & $(0.998)$ & -0.419 & (1.295) & 1.134 & $(1.638)$ \\
\hline & 0.084 & & 0.104 & & 0.292 & & 0.104 & \\
\hline Prob $>\chi^{2}$ & 0.000 & & 0.000 & & 0.000 & & 0.000 & \\
\hline Observations & 6052 & & 1273 & & 721 & & 4058 & \\
\hline
\end{tabular}

Panel-corrected standard errors in parentheses. Two-tailed significance tests used.

$* \mathrm{p} \leq 0.10 ; * * \mathrm{p} \leq 0.05 ; * * * \mathrm{p} \leq 0.01$

of US troops within the host-state increases by $1 \%$, the host-state decreases their defense burden by about 0.5 percentage points.

Panel 1 of Figure 3 shows only the most general effects. Panel 2 shows that non-NATO allies do not alter their defense burdens in response to increases in troops deployed to their territory. Panel 3 in Figure 3 shows the results for NATO members. These results provide support for Hypothesis 2 . When the average size of regional deployments around NATO allies reaches about 3,000 troops we see a statistically significant positive effect, indicating that NATO allies increase their defense spending when the US increases the number of troops within their borders, but only where regional deployments are large. Panel 4 shows that non-allies decrease their defense burdens in response to increases in deployments

\footnotetext{
${ }^{4}$ The difference between the effect in the non-NATO allies sample and the other models may be indistinguishable. See figure 4 for a comparison of where these effects are different from each other (Gelman and Stern 2006).
} 
to their states. As in Model 1, this effect is not distinguishable from zero at low levels of the regional deployment variable. However, this negative effect becomes different from zero when the average regional deployment size approaches approximately 20 troops.

(1)

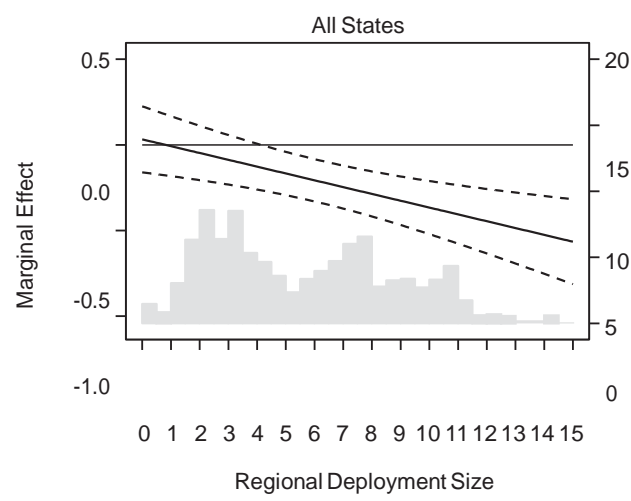

(3)

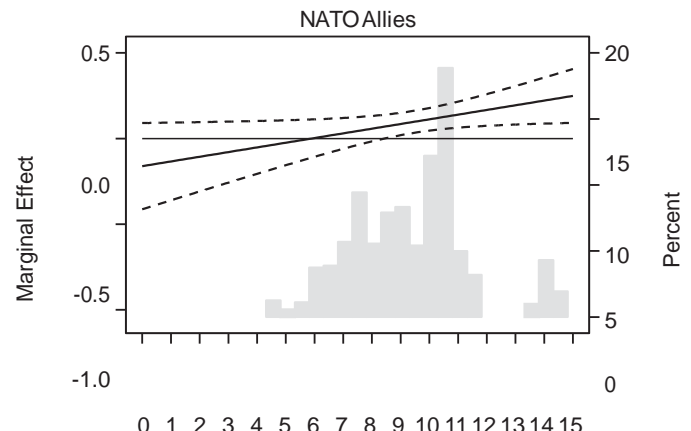

$0 \begin{array}{llllllllll}0 & 3 & 4 & 5 & 6 & 8 & 9 & 101112131415\end{array}$

Regional Deployment Size
(2)

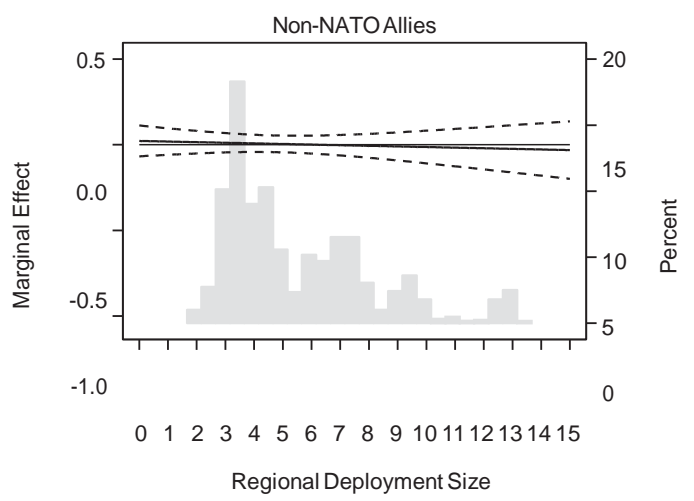

(4)

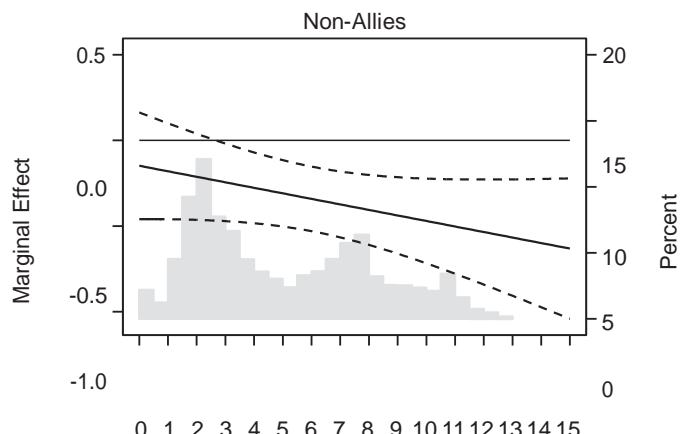

Regional Deployment Size

Figure 3: Marginal effect of an increase in the size of host-state deployment across the size of the regional deployment size. 95\% confidence intervals shown. Histogram represents the distribution of the X-axis variable as observed in the estimation sample.

Overall, these results provide us with insights into the relationship between US deploy- ments in and around the host-state and how those deployments affect the observed state's defense burdens. First, it appears that non-allies of the US are driving the results from Model 1. Panels 2 and 3 yield null and positive marginal effects, respectively. Only in the non-allied sample do states appear to respond to increasing internal US military deployments by decreasing their own defense spending. Furthermore, this effect is only significant once we have passed a minimal level of US troops deployed throughout the neighboring region. Though this value (i.e. 20) may seem small, it is important to remember that this is an average. The mean neighborhood size is approximately six states. In some cases the US may have stronger relationships with 2-3 states, meaning that some neighboring states are hosting larger deployments, while others may be hosting small deployments. ${ }^{5}$

These results suggest that alliance agreements between the US and a host-state also condition how the host-state responds to deployments. Existing alliance ties suggest that the US has already established a hierarchical relationship with the host-state and may already be offering physical or economic security in exchange for influence over foreign policy decision-making in the host state. Hence, the host-state may be less willing to give up additional sovereignty in exchange for troops. This may explain the lack of an effect for non-NATO ally sample (Model 2). On the other hand, 
non-allies do not have an existing security relationship with the US, so the presence of US troops within their state may be the only avenue by which the US is establishing a security relationship with the hoststate. Since the host-state did not previously concede sovereignty over foreign policy to the US through an alliance agreement, the host-state may be willing and able to give up more sovereignty (i.e. reduce their defense burden) in exchange for troops. ${ }^{1}$

Next, we examine the effect of $\ln$ (Troops Spatial Mean) on Defense Burden, given the size of host-state deployment. The results shown in Figure 4 provide support for Hypothesis 3 and the role of external hierarchies, especially in regard to the non-ally model. Panel 1 shows the results for the most general model (Model 1). Here we can see that when the US troop presence within a state is small or nonexistent, the marginal effect of an increase in the average size of regional US deployments correlates with an increase in the state's defense burden. In other words, when a low degree of internal hierarchy characterizes the relationship between the US and the observed state, that state will respond to increases in the US’ regional military presence by increasing its own defense expenditures.

The results for non-allied states (Panel 4) and non-NATO allies (Panel 2) also provide support for Hypothesis 4, indicating that a state's relationship with the US will condition how it responds to increases in regional deployment levels. Specifically, non-allied states hosting small deployments increase defense burdens as the neighborhood US troop presence increases in size. Once a non-allied state hosts a larger deployment $(\geq 20,000)$, we see a null effect. Alternatively, Panel 2 shows us that regardless of how many US troops a non-NATO ally hosts, non-NATO allies do not change their defense spending in relation to the number of US troops in their region. As per the discussion preceding Hypothesis 4, it is possible that the null result here reflects that non-NATO allies do not view regional US troop deployments as a threat due to their alliance with the US.

The results from Panel 3 of Figure 4 provides support for Hypothesis 5. When a NATO ally hosts more than approximately 1,100 US troops, it increases its defense burden when the US increases the size of regional deployments. This increase in spending likely reflects the emphasis NATO states have placed on burden sharing. In the context of NATO, a general increase in the size of US deployments to the region surrounding the host-state reflects a broad-based increase in the US' contributions to NATO's security and manpower. Although not all US military personnel may be directly attached to NATO, its member-states still benefit from the security provided by a larger US military presence. To put it differently, the bureaucratic organization of these troops is somewhat separate from the practical effects of their presence in or around a particular state. More generally, the results from Figure 4 further illustrate that the nature of alliance and hierarchcical relationships condition the influence of US troop deployments.

Some cases can help to illustrate these dynamics. After the 1979 peace treaty with

\footnotetext{
${ }^{1}$ We explore the possibility that some states with especially large defense burdens or deployments may be driving our results in the supplemental appendix. We include models that exclude Germany and Japan, given their historically high troop deployment levels and imposed restrictions on defense spending. Our results remain unchanged. See Table A1 in the Appendix, Figure A1 and Figure A2.
} 
(1)

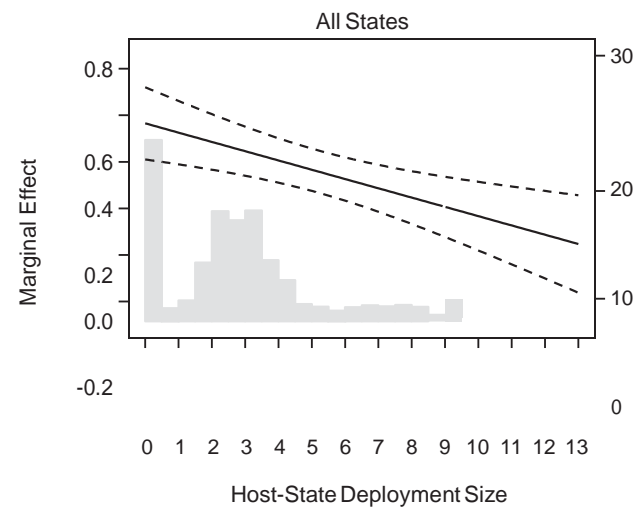

(3)

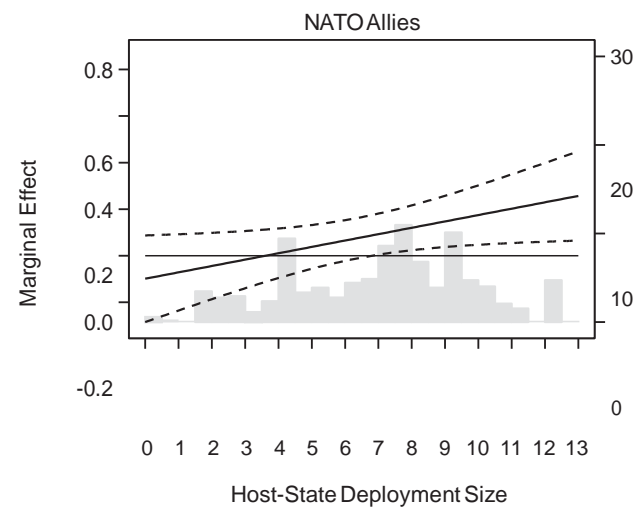

(2)

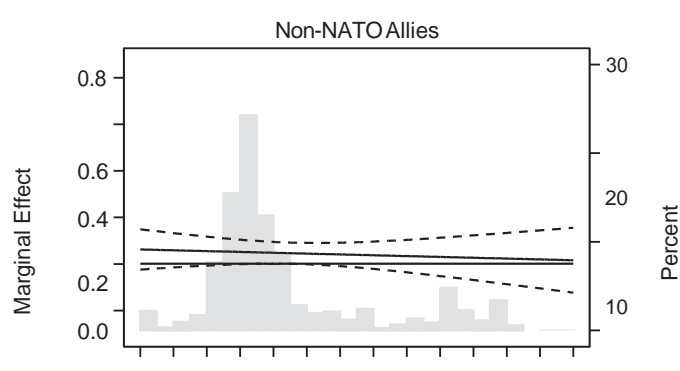

$-0.2$

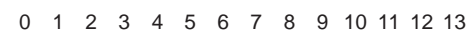

Host-State Deployment Size

(4)

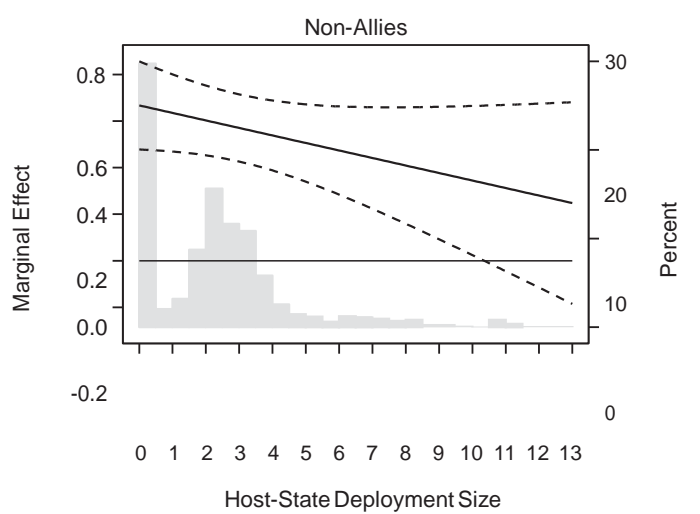

Figure 4: Marginal effect of an increase in the size of regional deployment across the size of the hoststate's deployment size. 95\% confidence intervals shown. Histogram represents the distribution of the Xaxis variable as observed in the estimation sample.

Israel, US military deployments to Egypt (a non-ally) increased from 136 in 1979 to over 1,000 in 1982, where it generally remained through the 1990s. Regional deployments were consistently above 800 during this time period. Despite a growing economy, Egypt's defense burden fell from a normal range of $3.5 \%-4.5 \%$ to just over $1 \%$ during the 1990 s. Though the end of the Cold War may partially explain this decline, Egypt maintained a defense burden of only 1.02\% in the First Gulf War; this level is actually lower than its burdens in the surrounding years. Alternatively, US deployments in and around Great Britain track the latter's defense burden quite closely. Great Britain's defense burden rises along with both direct and regional troop deployments in the 1950s, both types decline through the early 


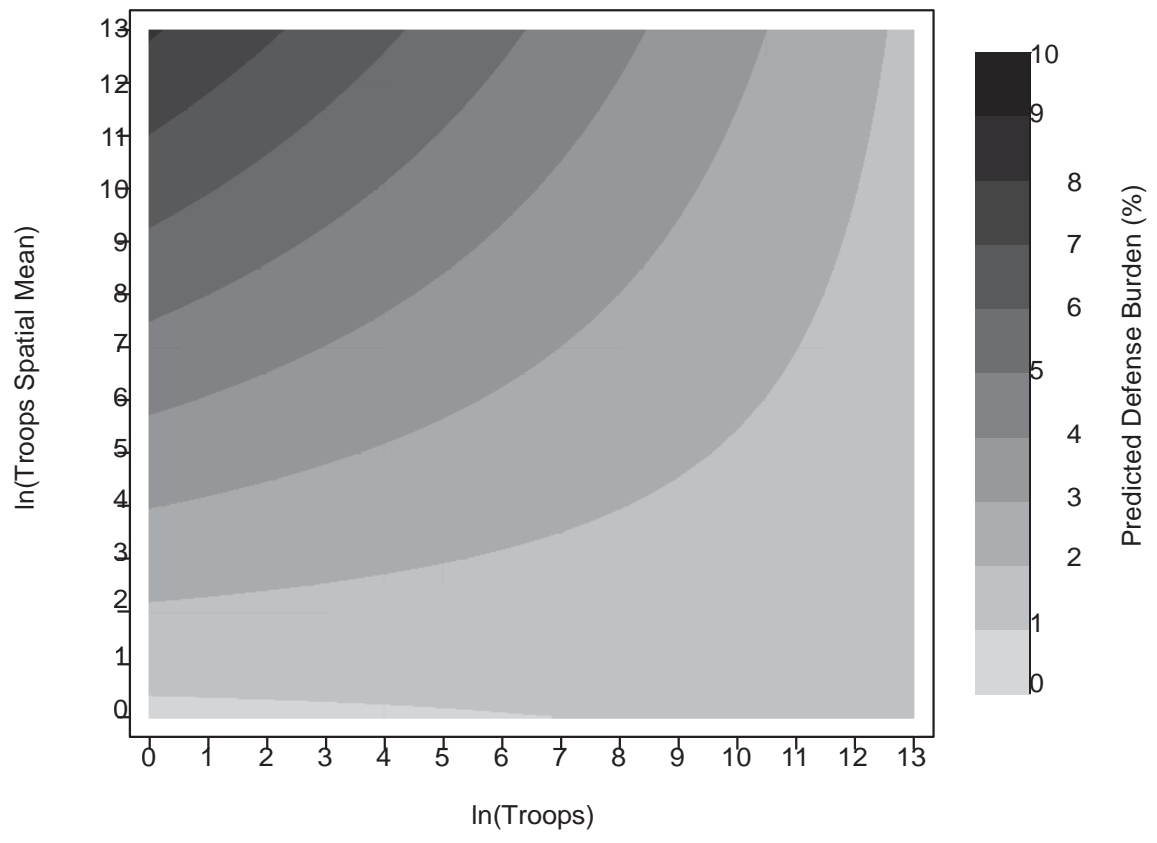

Figure 5: Predicted defense burden contour plot. $\mathrm{X}$ and $\mathrm{Y}$ axes represent the size of direct and regional troop deployments respectively. Shaded values represent the size of the observed state's defense burden, with darker colors indicating higher defense burdens. Predicted values generated using Model 1.

1960s, and increase slightly from the 1970s through the end of the Cold War, with only a brief spike in the defense burden during 1980. All other factors (i.e. alliance status, war, civil war, MID involvement, and threat environment) are more or less constant for both cases over these time periods.

Figure 5 provides insight into how direct and regional deployments affect host-state defense burdens. The $\mathrm{X}$ and $\mathrm{Y}$ axes show the range of the troops and spatial troops variables, respectively, while the darker shading indicates higher predicted defense burdens and the lighter shading indicates lower predicted defense burdens from our model general model (Model 1). It appears that the graph gets darker as the number of regional troops increases and lighter as the number of direct deployments increases, implying that higher regional deployments lead to higher defense spending and higher direct deployments lead to lower defense spending. Additionally, we can see that at low levels of direct deployments, increases in the average regional troop deployment size leads to an increase in the magnitude of the state's defense burden. However, as we increase the size of the referent state's troop deployment, increases in regional deployments correlate with smaller increases in defense burden, and ultimately no increase at the highest levels of the referent state's deployment size. Alternatively, for any given level of regional deployments, increasing the size of the deployment to the referent state generally correlates with a decrease in the predicted defense burden. However, this effect is much more pronounced for larger regional deployments than it is for smaller regional deployments. For example, when $\ln$ (TroopsSpatialMean) $=5$, we see a decline from $3-4 \%$ to $1-2 \%$ in the host-state's defense burden when we increase $\ln$ (Troops) from 0 to 13 . However, when $\ln ($ TroopsSpatialMean $)=10$, a similar increase in direct deployments reduces defense burdens from $7-8 \%$ to $1-2 \%$. Though such shifts are extreme, they help illustrate the conditional impact that direct and regional deployments have on host-state defense burdens.

We have run several robustness checks to determine if the end of the Cold War has impacted these relationships. Our results are all consistent throughout the Cold War period (see supplemental Appendix, tables A2 and A3 and figures A3-A8). In addition, only one of the post-Cold War models changed. The effects of host-state deployments in the non-ally sample cease to be statistically significant in the post- 
Cold War period. Though beyond the scope of our present analysis, the fact that the end of the Cold War did not result in a clear change in how states responded to US military deployments suggests other factors were at play. ${ }^{1}$

Importantly, these results hold when we control for other regional security factors. Figure 6 displays a coefficient plot for the spatial lag variable (Panel 1), as well as the spatial alliance measures (Panel 2). The spatial lag is positive and statistically significant across all four models, suggesting that states respond to increasing levels of military spending within the neighboring region by increasing their own spending. However, the magnitude of this effect varies substantially across the four samples. NATO and nonNATO allies of the US do respond to increases in regional defense expenditures by increasing their own, but this effect is small compared to non-allies of the US. Indeed, there is a large and statistically significant difference in the magnitude of this effect between the allied and non-allied samples. This may reflect that non-allies of the US do not have receive security "subsidies" through any sort of relationship with the US, making their own security provision efforts all the more important.

The spatial alliance variables shown in Panel 2 of Figure 6 are effectively proportional measures indicating how many states in the referent state's neighborhood are allies-either of the referent state itself, or of the US. Given their similar construction and that they measure similar concepts, comparisons between the two are informative. Splitting the samples in Models 2-4 is akin to interacting the alliance status of a state with the spatial alliance indicator, providing additional nuance to these variables.

The spatial alliance variable for the referent state positively correlates with defense bur- dens in the pooled sample (Model 1), the NATO sample (Model 3), and the non-allies sample (Model 4). This variable produces a null result in the non-NATO ally sample (Model 2). The positive coefficients in Models 1 , 3 , and 4 are surprising. States with more allies in their neighborhood appear to spend more on defense. We might think these states should spend less since the higher concentration of allies suggests that the amount of spending required to produce the same level of security should be less, all else being equal. However, such states may both spend more, and form more regional alliances, because of some sort of security threat. However, we control for a range of other variables that should capture such active and latent security pressures, and so this appears to be the independent effect of regional

(1)

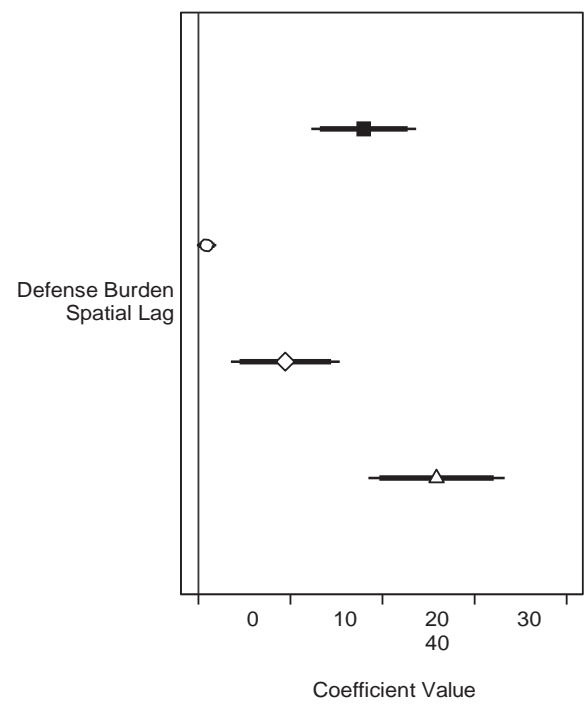

(2)

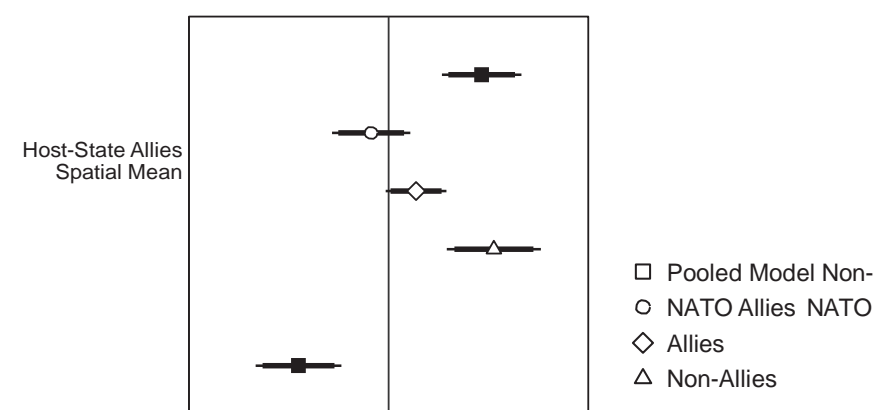

$\triangle$ Non-Allies

Figure 6: Coefficient plot for pooled model and alliance sub-sample models. 90\% and 95\% confidence intervals shown around coefficient point estimate.

\footnotetext{
${ }^{1}$ The slight overlap with the post-9/11 years does not affect our results. See table A4 and figures A9 and A10 in the supplemental Appendix.
} 
alliance ties. Thus, it is not clear what leads to these positive effects.

The spatial US allies variable also produces interesting results. Models 1 and 4 yield statistically significant negative coefficients. Non-allies appear to decrease defense spending as they find themselves surrounded by more US allies. The results from the pooled sample likely reflect the influence of these non-allied states in the estimation sample. Alternatively, we again see a null result for non-NATO allies of the US. Lastly, NATO states increase their defense burdens as proportionately more allies of the US surround them.

The results for the non-NATO ally model match the logic of our primary variables, and mirror the marginal effects discussed above. Given NATO's geographic concentration, the positive coefficient for NATO states in both models may similarly reflect burden sharing pressures. The null results for the non-NATO ally sample may reflect the idea that the referent state benefits from direct security guarantees, and so broader regional alliance patterns perhaps affect these states' defense burdens less clearly. The negative coefficient for non-allied states is less clear. We might think that non-allied states should respond to increasing regional security ties with the US by increasing their own defense expenditures. However, for some states, increasing homogeneity in their neighborhood may indicate greater stability and less need to increase defense spending. Though we often think of states like China, and Russia, most non-allied states of the US are not likely to possess the economic or military capabilities to meaningfully challenge US leadership in a region. The states included in the non-allied sample exhibit substantial variation in geographic location and economic development. Accordingly, a handful of outliers do not drive this negative result. Ultimately more research will be required to better understand how overlapping patterns in spatial alliance ties influence how states respond to both the US military presence, as well as security concerns posed by neighboring states.

\section{Conclusions}

Our results provide strong support our hypotheses, indicating that the influence of US troop deployments on host-state defense spending is conditional upon the broader regional context of those deployments. Most states will not decrease their defense burdens in exchange for more US troops if internal hierarchy is strong but external hierarchy is weak. However, as external hierarchy increases in size, the host-state will decrease its defense burden in exchange for more troops. While these relationships hold in the pooled sample, they tend to characterize non-allied states of the US. We find no evidence that non-NATO allies respond to changes in direct US military deployments. Alternatively, we do find that NATO allies respond in the hypothesized manner by increasing their defense expenditures in response to increases in the size of host-state troop deployments. These effects only hold, however, when a neighboring states also host a large number of US troops.

The findings also provide insights into how hosting US troops conditions a state's response to US deployments in the surrounding region. In our general model, we find that for states where internal hierarchy is weak, they respond to increases in external hierarchy by increasing their own defense burdens. However, when internal hierarchy increases, this positive effect eventually disappears. As with the conditioning effect of regional deployments, the conditioning effect of host-state deployments is clearest for the non-allied sub-sample. This indicates that these states do not share formal alliance ties with the US and tend to be more wary of regional power buildups, since the deployment of US military forces alone does not necessarily come with explicit guarantees in the conditions under which the US will aid in securing the non-ally. Alternatively, we find no evidence of an effect for non-NATO allies. We take this as further evidence that the security guarantees embodied by an alliance agreement greatly augment host-states responses to US troop deployments. We also find that NATO members increase their defense spending in response to regional troop buildups, but only once the state itself hosts a moderate number of US military forces. Member states that host a large number of US troops respond to regional increases in US troop deployments by increasing their own defense burden. We take this as confirming the idea that NATO states tend to follow the lead of the US in defense spending. In this case, increasing deployments is indicative of increasing US contributions to the NATO alliance more broadly, thereby 
prompting host-states to increase their own contributions. This supports the idea put forward by Lake (1999) who argues that the US used its authority over NATO member states in fundamentally different ways as compared to other allied states.

Our findings have broader theoretical and conceptual implications. Existing work on hierarchy and contractual security relationships approach the subject through a dyadic frame- work, divorced from broader regional context. As scholars of regional security have noted, relations between a state and major powers constitute only a part of a state's security concerns (Frazier and Stewart-Ingersoll 2010). Drawing on theoretical insights from both theories of hierarchy and theories of regional security relationships, our analysis has demonstrated that regional context matters in shaping how major powers like the US can use the provision of security to elicit policy concessions from states. States hosting US troop deployments do not lower their defense burdens unconditionally. US security relationships in the broader region create an environment of mutually reinforcing hierarchical relationships, wherein individual states are more responsive to the US as its broader regional influence grows. Future research should seek to develop improved theoretical and empirical approaches to understanding why the US chooses to use its authority in such areas differently, as in the case of NATO.

Similarly, researchers should examine how troop deployments by rival powers influence the dynamics explored herein as these models of internal and external hierarchy are isolated from competitor attempts to create their own hierarchies abroad. A ripe area for further exploration is to examine non-US troop deployments as rising (and declining) major powers create similar relationships in regions. While controlling for Warsaw Pact countries does not affect our findings, ${ }^{1}$ including Soviet troop deployments during the Cold War would add robustness to both the theoretical concepts we employ here and the empirical tests of those arguments. The deployment of Soviet forces to a region may dampen the effects of US military deployments, or may lead the US to use its authority over a state to promote higher levels of defense spending.

These findings are important for current foreign policy developments as the United States considers reducing and reallocating its foreign commitments abroad. Targeting specific countries for reductions will have dramatically different results than if the US pursued broad, regional reductions. Targeting states for deployment reductions may encourage the targeted state to spend more on their own military if the region already has a heavy US presence. However, reducing regional or targeted commitments to NATO countries may result in a reduction of defense commitments by both the state receiving the cuts as well as its neighbors.

\section{References}

Allen, Michael A. and Michael E. Flynn. 2013. "Putting Our Best Boots Forward: US Military Deploymentsand Host-Country Crime.” Conflict ManagementandPeaceScience 30(3):263-285.

Allen, Michael A., Michael E. Flynn and Julie VanDusky-Allen. 2014. "The Localized and Spatial Effects of US Troop Deployments on Host-State Defense Spending.” Foreign Policy Analysis pp. n/a-n/a.

Bailey, Michael A, Anton Strezhnev and Erik Voeten. 2015. "Estimating Dynamic State Preferences from United Nations Voting Data.” Journal of Conflict Resolution TBD(TBD).

Bell, Sam R, K Chad Clay and Carla Martinez Machain. 2016. "The Effect of US Troop Deployments on Human Rights.” Journal of Conflict Resolution OnlineFirst:1-24.

Berry, William D., Matt Golder and Daniel Milton. 2012. "Improving Tests of Theories Positing Interaction." The Journal of Politics 74(3):653-671.

Biglaiser, Glen and Karl DeRouen. 2007. "Following the Flag: Troop Deployments and US ForeignDirect Investment.” InternationalStudies Quarterly51(4):835-854.

Biglaiser, Glen and Karl DeRouen. 2009. "The interdependence of US troop deployments and trade in the developing world.” Foreign Policy Analysis 5(3):247-263.

Brown, J. N. 2013. "The sound of silence: Power, secrecy, and international audiences in US military basing negotiations." Conflict Management and Peace Science 31(4):406-431.

\footnotetext{
${ }^{1}$ See table A10 and figures A20-21 in the appendix.
} 

This is an author-produced, peer-reviewed version of this article. The final, definitive version of this document can be found online at
International Interactions, published by Routledge. Copyright restrictions may apply. doi: 10.1080/03050629.2016.1191482

Brown, Jonathan N. 2014. "Immovable Positions: Public Acknowledgment and Bargaining in MilitaryBasing Negotiations.” SecurityStudies 23(2):258-292.

Collier, Paul and Anke Hoeffler. 2002. Military Expenditure: Threats, Aid, and Arms Races. Technical report World Bank. URL: http://papers.ssrn.com/abstract $=636289$

Destradi, Sandra and Erich Gundlach. 2013. "Modeling external constraints on the hegemonic strategies of regional powers." Journal of Policy Modeling Forthcoming.

Frazier, Derrick and Robert Stewart-Ingersoll. 2010. "Regional Powers and Security: A Framework for Understanding Order within Regional Security Complexes.” European Journal of International Relations 16(4):731-753.

Gelman, Andrew and Hal Stern. 2006. "The difference between "significant" and "not significant" is not itself statistically significant.” The American Statistician 60(4):328-331.

Gleditsch, Kristian Skrede. 2002. "Expanded trade and GDP data." Journal of Conflict Resolution 46(5):712724.

Goldsmith, Benjamin E. 2007. “Arms Racing in 'Space': Spatial Modelling of Military Spending around the World.” Australian Journal of Political Science 42(3):419-440.

Ikenberry, G. John. 2011. Liberal Leviathan: The Origins, Crisis, and Transformation of the American World Order. Princeton: Princeton University Press.

Jones, Garett and Tim Kane. 2012. “US Troop Deployments and Foreign Economic Growth.” Defence and Peace Economics 23(3):225-249.

Kane, Timothy. 2006. “Global US troop deployment, 1950-2005.” Center for Data Analysis CDA06.

Lake, David A. 1999. Entangling Relations: American Foreign Policyinits Century. Princeton: Princeton University Press.

Lake, David A. 2001. "Beyond anarchy: The importance of security institutions.” International Security 26(1):129-160.

Lake, David A. 2009a. Hierarchy in International Relations. Cornell University Press.

Lake, David A. 2009b. "Regional hierarchy: authority and local international order." Review of International Studies 35(S1):35-58.

Leeds, Brett Ashley, Jeffrey M. Ritter, Sara McLaughlin Mitchell and Andrew G. Long. 2002. “Alliance treaty obligations and provisions, 1815-1944.” International Interactions 28:237-260.

Martinez Machain, Carla and T. Clifton Morgan. 2013. "The Effect of US Troop Deployment on Host States' Foreign Policy.” Armed Forces and Society 39(1):102-123.

Morrow, James D. 1991. "Alliances and Asymmetry: An Alternative to the Capability Aggregation Model of Alliances.” AmericanJournalofPoliticalScience35(4):904-933.

Neumayer, Eric and Thomas Plümper. 2016. "W.” Political Science Research and Methods 4(1).

Palmer, Glenn. 1990a. "Alliance politics and issue areas: Determinants of defense spending.” American Journal of Political Science 34(1):190-211.

Palmer, Glenn. 1990b. “Corralling the free rider: Deterrence and the Western alliance.” International Studies Quarterly 34(2):147-164.

Sandler, Todd. 1988. “Sharing burdens in NATO.” Challenge 31(2):29-35.

Sarkees, Meredeith Reid and Frank Wayman. 2010. Resort to war: 1816-2007. Washington, D.C.: CQ Press.

Schelling, Thomas C. 1966. Arms and Influence. New Haven, CT:: Yale University Press.

Singer, J. David. 1987. "Reconstructing the Correlates of War dataset on material capabilities of states, 18161985.” International Interactions 14:115-132.

Stinnett, Douglas M., Jaroslav Tir, Philip Schafer, Paul F. Diehl and Charles Gochman. 2002. "The correlates of war project direct contiguity data, version 3." Conflict Management and PeaceScience 19(2):58-66.

United States Department of Defense. 2003. Allied Contributions to the Common Defense.

Technical report United States Department of Defense Washington, D.C.:. URL: http://archive.defense.gov/pubs/alliedcontrib2003/Allied2003Chap2.html

Ward, Michael D. and Kristian Skrede Gleditsch. 2008. Spatial Regression Models. Thousand Oaks, CA: SAGE Publications.

Wooldridge, Jeffrey M.2010. Econometric AnalysisofCross SectionandPanelData. Second ed. Cambridge: The MIT Press. 


\section{Appendix}

\section{Contents}

A Control Variables 3

B Robustness Checks 4

\section{List of Tables}

A1 US Troop Deployments and Host-State Defense Burdens. Models exclude Germany and Japan from the relevant estimation samples. . . . . . . . . . .

A2 US Troop Deployments and Host-State Defense Burdens. Models run on Cold War years only $(1950-1990) \ldots \ldots \ldots \ldots \ldots$

A3 US Troop Deployments and Host-State Defense Burdens. Models run on Post-Cold War years only (1991-2003). . . . . . . . . . . . . . . . . . . 8

A4 US Troop Deployments and Host-State Defense Burdens. Models run on Pre-War on Terror years only $(1950-2000)$. . . . . . . . . . . . . . . . . . 10

A5 US Troop Deployments and Host-State Defense Burdens. Includes Spatial MIDs variable for referent state regional conflict. . . . . . . . . . . . . . . 11

A6 US Troop Deployments and Host-State Defense Burdens. Deployments below 20 are counted as $0 \ldots \ldots \ldots \ldots \ldots$. . . . . . . . . . . . . . . 13

A7 US Troop Deployments and Host-State Defense Burdens. Deployments below 100 are counted as $0 . \ldots \ldots \ldots$. . . . . . . . . . . . . . . . 15

A8 US Troop Deployments and Host-State Defense Burdens. Subsamples based on UN voting absolute ideal point distance percentiles. . . . . . . . . . . . . 18

A9 US Troop Deployments and Host-State Defense Burdens. Models estimated using $\frac{1}{G D P}$ as the dependent variable. . . . . . . . . . . . . . . . . . . . 19

A10 US Troop Deployments and Host-State Defense Burdens. Model 4 includes Warsaw Pact Membership Variable. . . . . . . . . . . . . . . . . . . . 20

A11 Model Comparison Table . . . . . . . . . . . . . . . . . . . . . . . . . . . 22

\section{List of Figures}

A1 Marginal effect plot for pooled model and alliance sub-sample models. 95\% confidence intervals shown around coefficient point estimate. Models exclude both Germany and Japan from the relevant estimation samples. . . . . . . .

A2 Marginal effect plot for pooled model and alliance sub-sample models. 95\% confidence intervals shown around coefficient point estimate. Models exclude both Germany and Japan from the relevant estimation samples. . . . . . . .

A3 Marginal effect plot for pooled model and alliance sub-sample models. 95\% confidence intervals shown around coefficient point estimate. Models run on

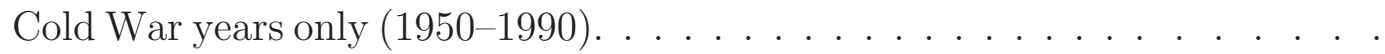


A4 Marginal effect plot for pooled model and alliance sub-sample models. $95 \%$ confidence intervals shown around coefficient point estimate. Models run on Cold War years only $(1950-1990)$. . . . . . . . . . . . . . . . . . . . . . .

A5 Coefficient plot for pooled model and alliance sub-sample models. $90 \%$ and 95\% confidence intervals shown around coefficient point estimate. Models run on Cold War years only $(1950-1990)$. . . . . . . . . . . . . . . . . . . . . .

A6 Marginal effect plot for pooled model and alliance sub-sample models. 95\% confidence intervals shown around coefficient point estimate. Models run on Post-Cold War years only $(1991-2003)$. . . . . . . . . . . . . . . . . . . . . .

A7 Marginal effect plot for pooled model and alliance sub-sample models. 95\% confidence intervals shown around coefficient point estimate. Models run on Post-Cold War years only $(1991-2003)$. . . . . . . . . . . . . . . . . . . . .

A8 Coefficient plot for pooled model and alliance sub-sample models. $90 \%$ and 95\% confidence intervals shown around coefficient point estimate. Models run on Post-Cold War years only $(1991-2003)$. . . . . . . . . . . . . . . . . . . .

A9 Marginal effect plot for pooled model and alliance sub-sample models. 95\% confidence intervals shown around coefficient point estimate. Models cover only 1950-2000 to exclude years associated with the War on Terror. . . . . .

A10 Marginal effect plot for pooled model and alliance sub-sample models. 95\% confidence intervals shown around coefficient point estimate. Models cover only 1950-2000 to exclude years associated with the War on Terror. . . . . . .

A11 Marginal effect plot for pooled model and alliance sub-sample models. 95\% confidence intervals shown around coefficient point estimate. Models include spatial MIDs variable. . . . . . . . . . . . . . . . . . . . . . . . . . . .

A12 Marginal effect plot for pooled model and alliance sub-sample models. 95\% confidence intervals shown around coefficient point estimate. Models include spatial MIDs variable. . . . . . . . . . . . . . . . . . . . . . . . . . . .

A13 Marginal effect plot for pooled model and alliance sub-sample models. 95\% confidence intervals shown around coefficient point estimate. Deployments below 20 are counted as $0 \ldots \ldots$. . . . . . . . . . . . . . . . . . . . .

A14 Marginal effect plot for pooled model and alliance sub-sample models. 95\% confidence intervals shown around coefficient point estimate. Deployments below 20 are counted as $0 \ldots \ldots$. . . . . . . . . . . . . . . . . . . .

A15 Marginal effect plot for pooled model and alliance sub-sample models. 95\% confidence intervals shown around coefficient point estimate. Deployments

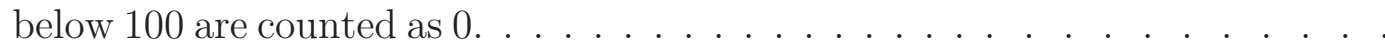

A16 Marginal effect plot for pooled model and alliance sub-sample models. 95\% confidence intervals shown around coefficient point estimate. Deployments

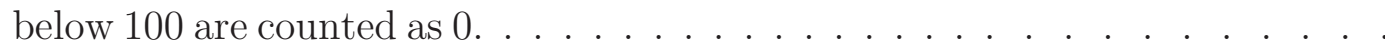

A17 Marginal effect plot for pooled model and alliance sub-sample models. 95\% confidence intervals shown around coefficient point estimate. Panels show UN voting ideal point distance from the US in quartiles. . . . . . . . . . . . . . .

A18 Marginal effect plot for pooled model and alliance sub-sample models. 95\% confidence intervals shown around coefficient point estimate. Panels show UN voting ideal point distance from the US in quartiles. . . . . . . . . . . . . . . 
A19 Marginal effect plot for pooled model and alliance sub-sample models using $\frac{1}{G D P}$ as the dependent variable. $95 \%$ confidence intervals shown around coefficient point estimate. . . . . . . . . . . . . . . . . . . .

A20 Marginal effect for increase in host-state troop deployments for non-allies of the US. Model includes Warsaw Pact dummy variable. . . . . . . . . . . . . . 21

A21 Marginal effect for increase in regional troop deployments for non-allies of the US. Model includes Warsaw Pact dummy variable. . . . . . . . . . . . . .

\section{A Control Variables}

Our models include a number of control variables that have been linked to states' defense burdens.

We include the 21-point measure of Polity from the Polity IV dataset as we expect democratic states to spend less on their military (Fordham and Walker 2005; Marshall, Jaggers and Gurr 2011). ${ }^{1}$

We also include the annual percentage change in GDP to account for Growth (Gleditsch 2002).

To account for the trade-off between defense spending and domestic demands for spending on other social issues, we include the Infant Mortality Rate in a country. Previous studies suggest that the infant mortality rate acts as an exogenous pressure for social spending and allows us to control for a negative pressure on defense burdens (Abouharb and Kimball 2007; Allen and Digiuseppe 2013; Kimball 2010).

We also expect larger states to spend more on defense, and so we include a logged measure of the observed state's total population, $\ln$ (Population), using data from the COW National Material Capabilities dataset (v4.0) (Singer 1987).

We also control for military and security pressures that may condition both defense spending and troop deployments to a country. We account for whether a state is in an Interstate War during the observed year (Sarkees and Wayman 2010), the number of Militarized Interstate Disputes $(M I D s)$ involving the country over the previous three years (Ghosn, Palmer and Bremer 2004), and the global Threat Environment a country faces (Leeds and Savun 2007). We generate the first two variables using the COW interstate war and militarized interstate dispute datasets (versions 4.0 and 4.1, respectively). We follow Leeds and Savun (2007) to construct the threat environment variable, which takes into account CINC scores. ${ }^{2}$ We also control for the number of Border States surrounding a country as a measure of the opportunities for conflict a state has (Bremer 1992; Stinnett et al. 2002). Lastly, we also control for incidence of Civil War using the COW intra-state war data (v4.1) (Sarkees and Wayman 2010).

\footnotetext{
${ }^{1}$ We use the 2011 release of the Polity data.

${ }^{2}$ This variable is the sum of the CINC scores for pairs of states with an S score that is less than the global median S score, calculated for all politically relevant dyads (Signorino and Ritter 1999). We use the scompute command in Stata to calculate S scores (Sweeney and Keshk 2005). We obtained the CINC data from the COW NMC data (Singer 1987).
} 


\section{B Robustness Checks}

Table A1: US Troop Deployments and Host-State Defense Burdens. Models exclude Germany and Japan from the relevant estimation samples.

\begin{tabular}{|c|c|c|c|c|c|c|c|c|}
\hline \multirow[b]{2}{*}{$\ln$ (Troops) } & \multicolumn{2}{|c|}{$\begin{array}{c}(1) \\
\text { All States }\end{array}$} & \multicolumn{2}{|c|}{$\begin{array}{c}(2) \\
\text { Non-NATO Allies }\end{array}$} & \multicolumn{2}{|c|}{$\begin{array}{c}(3) \\
\text { NATO Allies }\end{array}$} & \multicolumn{2}{|c|}{$\begin{array}{c}(4) \\
\text { Non-Allies }\end{array}$} \\
\hline & 0.016 & $(0.100)$ & 0.022 & $(0.046)$ & -0.167 & $(0.145)$ & -0.201 & $(0.166)$ \\
\hline ln (Troops Spatial Mean) & $0.536^{* * *}$ & $(0.080)$ & 0.063 & $(0.044)$ & -0.101 & $(0.102)$ & $0.577^{* * *}$ & $(0.100)$ \\
\hline Troops $\times$ Troops Spatial Mean & $-0.038^{* * *}$ & $(0.013)$ & -0.004 & $(0.008)$ & $0.028^{* *}$ & $(0.014)$ & -0.020 & $(0.023)$ \\
\hline Spatial Lag & $24.368^{* * *}$ & $(3.674)$ & $0.894^{*}$ & $(0.534)$ & $8.397^{* * *}$ & $(2.967)$ & $41.516^{* * *}$ & $(5.478)$ \\
\hline Host-State Allies (Spatial Mean) & $1.944^{* * *}$ & $(0.440)$ & -0.381 & $(0.435)$ & $0.668^{* *}$ & $(0.339)$ & $2.089^{* * *}$ & $(0.522)$ \\
\hline US Allies (Spatial Mean) & $-1.807^{* * *}$ & $(0.476)$ & -0.027 & $(0.558)$ & $0.560^{* *}$ & $(0.281)$ & $-2.036^{* *}$ & $(0.845)$ \\
\hline Polity & $-0.088^{* * *}$ & $(0.013)$ & $-0.018^{* * *}$ & $(0.006)$ & $-0.031^{*}$ & $(0.016)$ & $-0.111^{* * *}$ & $(0.018)$ \\
\hline Growth & -0.004 & $(0.007)$ & -0.001 & $(0.003)$ & 0.001 & $(0.005)$ & -0.004 & $(0.008)$ \\
\hline $\ln$ (Population) & -0.047 & $(0.140)$ & -0.081 & $(0.098)$ & $0.327^{* * *}$ & $(0.071)$ & 0.007 & $(0.162)$ \\
\hline Infant Mortality Rate & $-0.007^{*}$ & $(0.004)$ & -0.001 & $(0.001)$ & $0.006^{*}$ & $(0.003)$ & $-0.008^{*}$ & $(0.005)$ \\
\hline Interstate War & $1.421^{* * *}$ & $(0.324)$ & $0.259^{*}$ & $(0.143)$ & 0.169 & $(0.105)$ & $2.317^{* * *}$ & $(0.533)$ \\
\hline Civil War & $0.677^{* *}$ & $(0.288)$ & 0.000 & $(0.075)$ & 0.098 & $(0.115)$ & $0.829^{* *}$ & $(0.376)$ \\
\hline MIDs & 0.129 & $(0.131)$ & $0.134^{*}$ & $(0.073)$ & 0.006 & $(0.052)$ & 0.157 & $(0.166)$ \\
\hline Threat Environment & $-3.264^{* * *}$ & $(0.844)$ & $-1.027^{*}$ & $(0.532)$ & $-1.330^{* *}$ & $(0.677)$ & $-2.779^{* *}$ & $(1.306)$ \\
\hline \# Border States & 0.121 & $(0.084)$ & 0.041 & $(0.049)$ & -0.008 & $(0.042)$ & 0.074 & $(0.107)$ \\
\hline Constant & 1.414 & $(1.381)$ & $2.411^{* *}$ & $(0.998)$ & -0.283 & $(1.385)$ & 0.461 & $(1.645)$ \\
\hline$R^{2}$ & 0.088 & & 0.104 & & 0.304 & & 0.114 & \\
\hline Prob $>\chi^{2}$ & 0.000 & & 0.000 & & 0.000 & & 0.000 & \\
\hline Observations & 5955 & & 1273 & & 675 & & 4007 & \\
\hline
\end{tabular}

Panel-corrected standard errors in parentheses. Two-tailed significance tests used.

$* \mathrm{p} \leq 0.10 ; * * \mathrm{p} \leq 0.05 ; * * * \mathrm{p} \leq 0.01$

(1)

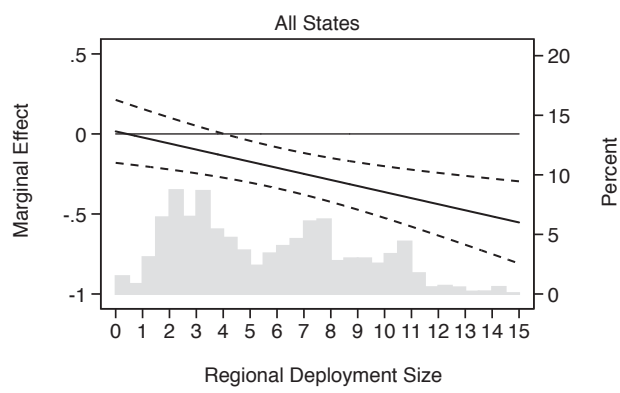

(3)

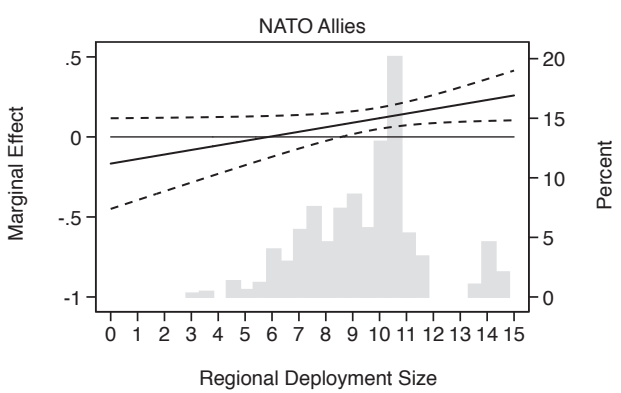

(2)

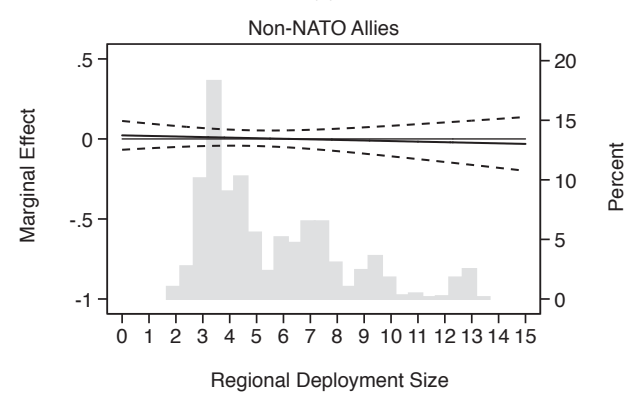

(4)

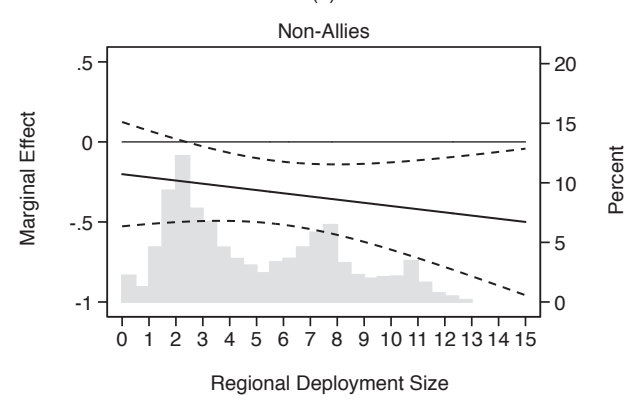

Figure A1: Marginal effect plot for pooled model and alliance sub-sample models. 95\% confidence intervals shown around coefficient point estimate. Models exclude both Germany and Japan from the relevant estimation samples. 

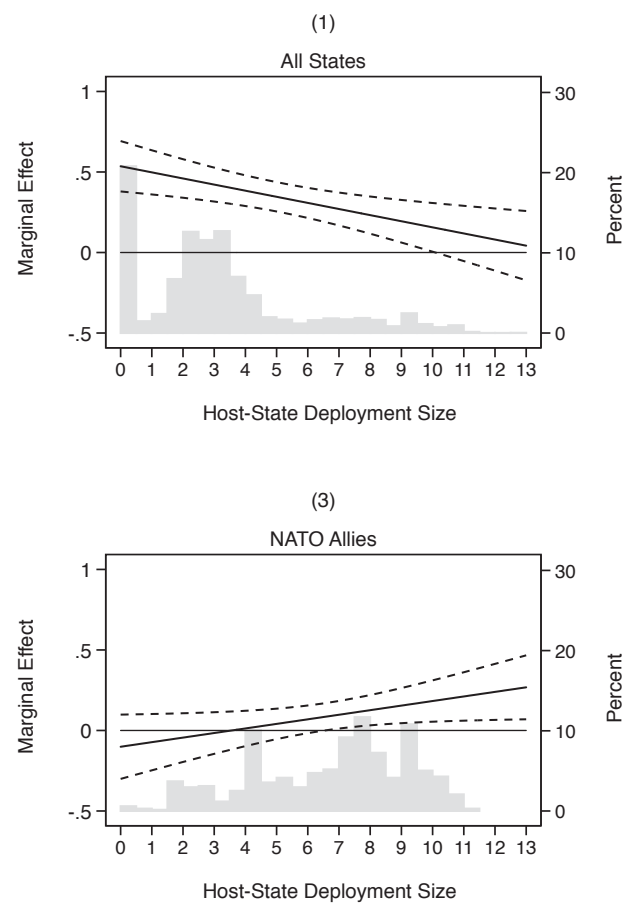
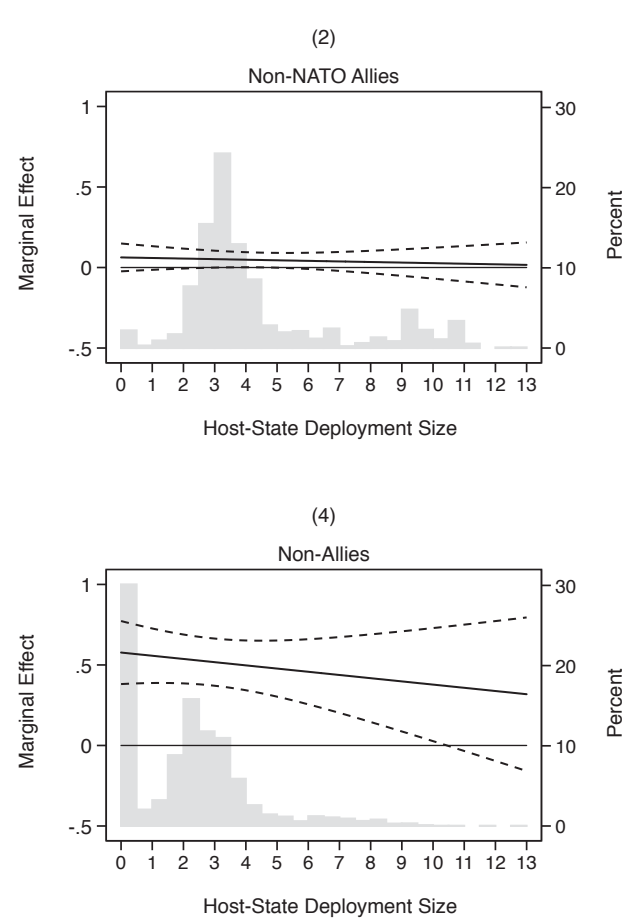

Figure A2: Marginal effect plot for pooled model and alliance sub-sample models. 95\% confidence intervals shown around coefficient point estimate. Models exclude both Germany and Japan from the relevant estimation samples.

Table A2: US Troop Deployments and Host-State Defense Burdens. Models run on Cold War years only (1950-1990).

\begin{tabular}{|c|c|c|c|c|c|c|c|c|}
\hline \multirow[b]{2}{*}{$\ln$ (Troops) } & \multicolumn{2}{|c|}{$\begin{array}{c}(1) \\
\text { All States }\end{array}$} & \multicolumn{2}{|c|}{$\begin{array}{c}(2) \\
\text { Non-NATO Allies }\end{array}$} & \multicolumn{2}{|c|}{$\begin{array}{c}(3) \\
\text { NATO Allies }\end{array}$} & \multicolumn{2}{|c|}{$\begin{array}{c}(4) \\
\text { Non-Allies }\end{array}$} \\
\hline & 0.013 & $(0.089)$ & -0.014 & $(0.060)$ & $-0.642^{* * *}$ & $(0.181)$ & -0.179 & $(0.150)$ \\
\hline ln (Troops Spatial Mean) & $0.577^{* * *}$ & $(0.112)$ & 0.068 & $(0.056)$ & $-0.454^{* * *}$ & $(0.137)$ & $0.727^{* * *}$ & $(0.139)$ \\
\hline Troops $\times$ Troops Spatial Mean & $-0.042^{* * *}$ & $(0.014)$ & -0.003 & $(0.009)$ & $0.070^{* * *}$ & $(0.018)$ & $-0.037^{*}$ & $(0.023)$ \\
\hline Spatial Lag & $9.342^{* * *}$ & $(2.111)$ & 0.638 & $(0.533)$ & $8.051^{* *}$ & (3.658) & $15.189^{* * *}$ & (3.291) \\
\hline Host-State Allies (Spatial Mean) & $2.077^{* * *}$ & $(0.475)$ & -0.340 & $(0.523)$ & $0.825^{*}$ & $(0.437)$ & $2.625^{* * *}$ & $(0.573)$ \\
\hline US Allies (Spatial Mean) & $-2.627^{* * *}$ & $(0.470)$ & 0.516 & $(0.703)$ & 0.494 & $(0.330)$ & $-3.061^{* * *}$ & $(0.870)$ \\
\hline Polity & $-0.073^{* * *}$ & $(0.013)$ & $-0.016^{* *}$ & $(0.006)$ & $-0.034^{* *}$ & $(0.017)$ & $-0.122^{* * *}$ & $(0.021)$ \\
\hline Growth & 0.004 & $(0.005)$ & -0.004 & $(0.003)$ & -0.000 & $(0.006)$ & 0.006 & $(0.006)$ \\
\hline ln (Population) & -0.047 & $(0.154)$ & -0.142 & $(0.135)$ & $0.416^{* * *}$ & $(0.086)$ & -0.004 & $(0.176)$ \\
\hline Infant Mortality Rate & $-0.007^{* *}$ & $(0.003)$ & -0.002 & $(0.002)$ & -0.000 & $(0.004)$ & $-0.008^{* *}$ & $(0.003)$ \\
\hline Interstate War & $0.774^{* * *}$ & $(0.285)$ & $0.325^{*}$ & $(0.189)$ & $0.306^{*}$ & $(0.182)$ & $1.101^{* * *}$ & $(0.418)$ \\
\hline Civil War & 0.068 & $(0.221)$ & -0.029 & $(0.100)$ & 0.083 & $(0.155)$ & 0.126 & $(0.301)$ \\
\hline MIDs & $0.368^{* * *}$ & $(0.104)$ & 0.124 & $(0.089)$ & 0.101 & $(0.065)$ & $0.481^{* * *}$ & $(0.130)$ \\
\hline Threat Environment & $-3.298^{* * *}$ & $(0.931)$ & $-2.460^{* * *}$ & $(0.650)$ & $-1.728^{*}$ & $(0.939)$ & -0.715 & $(1.522)$ \\
\hline \# Border States & 0.125 & $(0.079)$ & 0.047 & $(0.064)$ & 0.064 & $(0.049)$ & 0.029 & $(0.101)$ \\
\hline Constant & 2.433 & $(1.484)$ & $3.651^{* * *}$ & $(1.411)$ & $3.227^{*}$ & $(1.682)$ & 1.201 & $(1.736)$ \\
\hline$R^{2}$ & 0.103 & & 0.125 & & 0.377 & & 0.125 & \\
\hline Prob $>\chi^{2}$ & 0.000 & & 0.000 & & 0.000 & & 0.000 & \\
\hline Observations & 4183 & & 940 & & 513 & & 2730 & \\
\hline
\end{tabular}

Panel-corrected standard errors in parentheses. Two-tailed significance tests used.

$* \mathrm{p} \leq 0.10 ; * * \mathrm{p} \leq 0.05 ; * * * \mathrm{p} \leq 0.01$ 
(1)

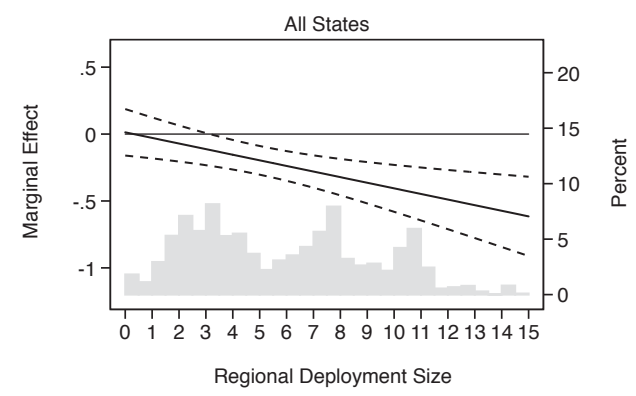

(3)

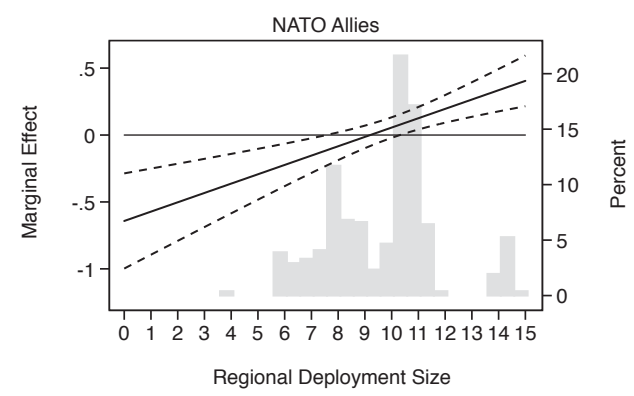

(2)

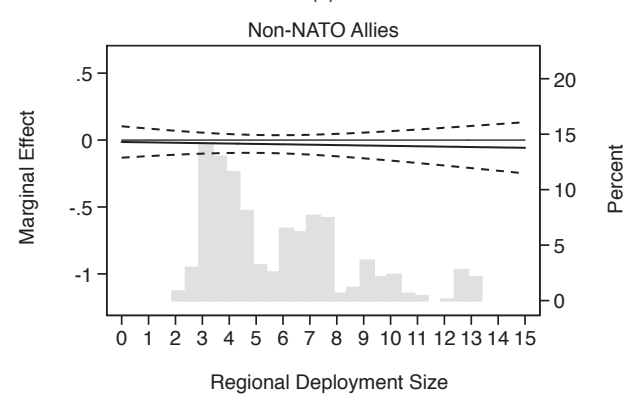

(4)

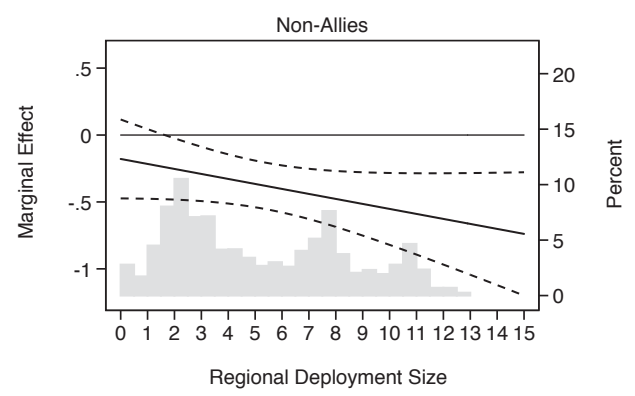

Figure A3: Marginal effect plot for pooled model and alliance sub-sample models. 95\% confidence intervals shown around coefficient point estimate. Models run on Cold War years only (1950-1990). 
(1)

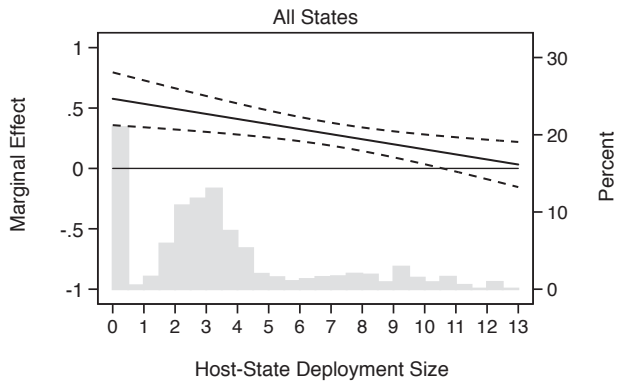

(3)

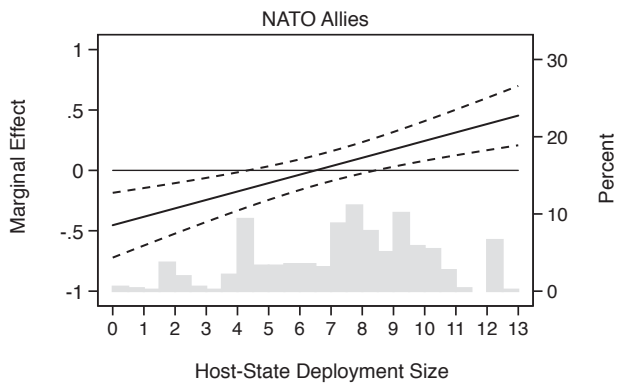

(2)

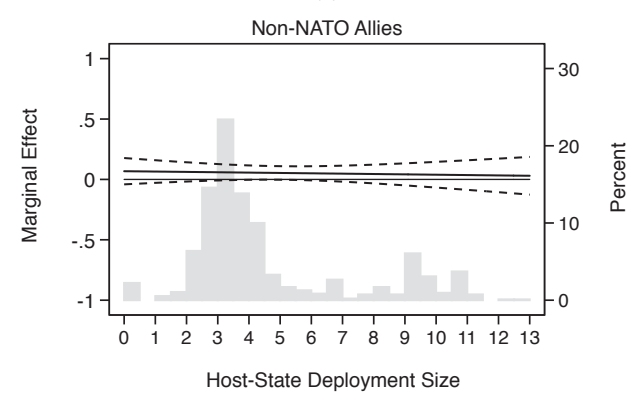

(4)

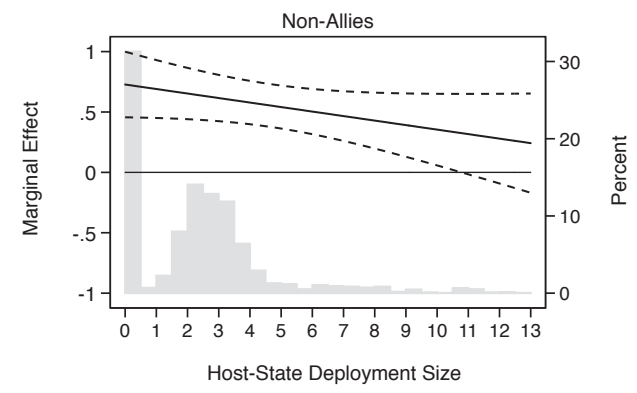

Figure A4: Marginal effect plot for pooled model and alliance sub-sample models. 95\% confidence intervals shown around coefficient point estimate. Models run on Cold War years only (1950-1990).
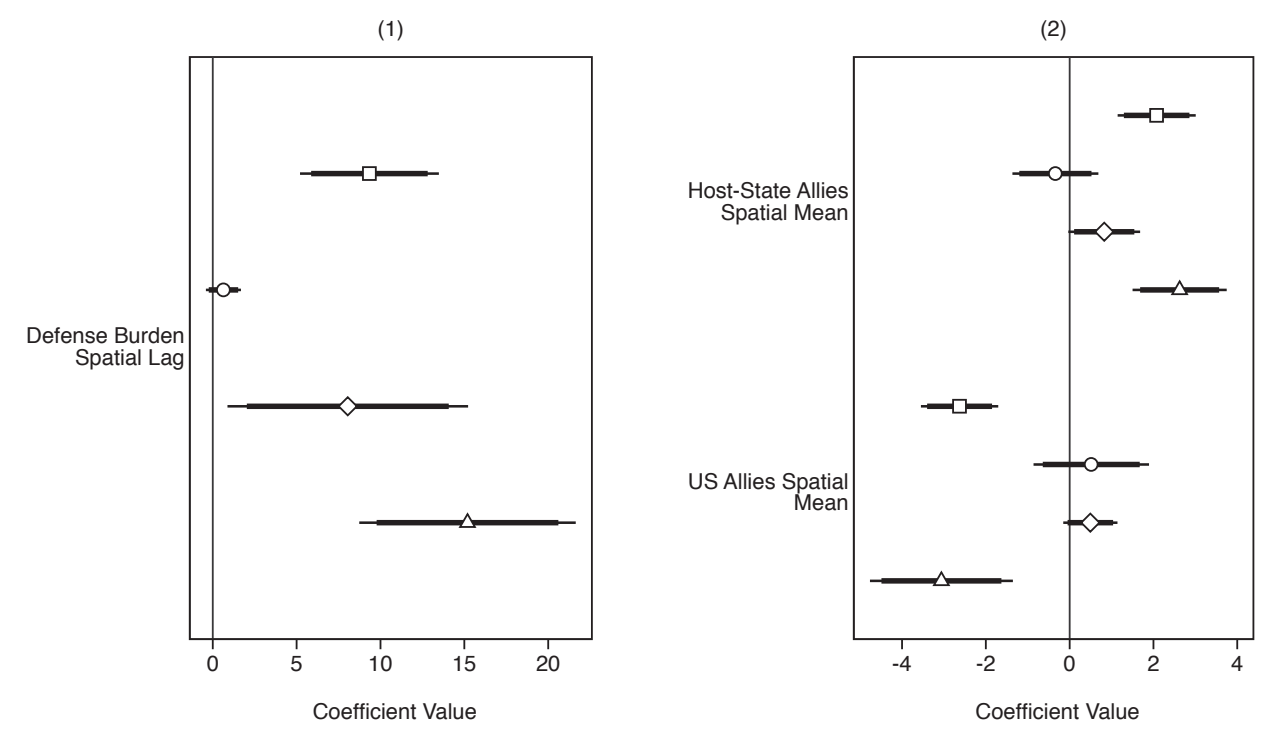

$\square$ Pooled Model

O Non-NATO Allies

$\diamond$ NATO Allies

$\triangle$ Non-Allies

Figure A5: Coefficient plot for pooled model and alliance sub-sample models. 90\% and 95\% confidence intervals shown around coefficient point estimate. Models run on Cold War years only (1950-1990). 
Table A3: US Troop Deployments and Host-State Defense Burdens. Models run on PostCold War years only (1991-2003).

\begin{tabular}{|c|c|c|c|c|c|c|c|c|}
\hline \multirow[b]{2}{*}{$\ln$ (Troops) } & \multicolumn{2}{|c|}{$\begin{array}{c}(1) \\
\text { All States }\end{array}$} & \multicolumn{2}{|c|}{$\begin{array}{c}(2) \\
\text { Non-NATO Allies }\end{array}$} & \multicolumn{2}{|c|}{$\begin{array}{c}(3) \\
\text { NATO Allies }\end{array}$} & \multicolumn{2}{|c|}{$\begin{array}{c}(4) \\
\text { Non-Allies }\end{array}$} \\
\hline & 0.158 & $(0.159)$ & 0.014 & $(0.050)$ & $-0.149^{*}$ & $(0.083)$ & -0.004 & $(0.238)$ \\
\hline ln (Troops Spatial Mean) & $0.350^{* * *}$ & $(0.128)$ & $-0.067^{*}$ & $(0.038)$ & -0.010 & $(0.038)$ & $0.423^{* * *}$ & $(0.141)$ \\
\hline Troops $\times$ Troops Spatial Mean & $-0.055^{* *}$ & $(0.026)$ & 0.002 & $(0.009)$ & $0.035^{* * *}$ & $(0.011)$ & -0.046 & $(0.037)$ \\
\hline Spatial Lag & $46.931^{* * *}$ & $(12.149)$ & $12.084^{* * *}$ & $(4.125)$ & 9.891 & $(6.666)$ & $49.214^{* * *}$ & (11.997) \\
\hline Host-State Allies (Spatial Mean) & $1.801^{* * *}$ & $(0.625)$ & 0.242 & $(0.474)$ & $-1.425^{*}$ & $(0.735)$ & $1.790^{* * *}$ & $(0.669)$ \\
\hline US Allies (Spatial Mean) & $-1.102^{*}$ & $(0.668)$ & $-1.536^{* *}$ & $(0.681)$ & $1.139^{* * *}$ & $(0.389)$ & $-3.096^{* *}$ & $(1.494)$ \\
\hline Polity & $-0.113^{* * *}$ & $(0.027)$ & -0.010 & $(0.010)$ & -0.042 & $(0.158)$ & $-0.106^{* * *}$ & $(0.022)$ \\
\hline Growth & -0.024 & $(0.024)$ & 0.004 & $(0.007)$ & -0.019 & $(0.017)$ & -0.026 & $(0.025)$ \\
\hline $\ln$ (Population) & -0.069 & $(0.192)$ & -0.120 & $(0.115)$ & 0.080 & $(0.075)$ & 0.078 & $(0.229)$ \\
\hline Infant Mortality Rate & $-0.022^{* * *}$ & $(0.008)$ & -0.003 & $(0.002)$ & -0.008 & $(0.010)$ & $-0.024^{* *}$ & $(0.010)$ \\
\hline Interstate War & $3.556^{* * *}$ & $(0.787)$ & -0.066 & $(0.103)$ & 0.193 & $(0.146)$ & $8.142^{* * *}$ & $(1.342)$ \\
\hline Civil War & $1.498^{* * *}$ & $(0.498)$ & -0.038 & $(0.094)$ & $0.372^{*}$ & $(0.221)$ & $1.485^{* * *}$ & $(0.559)$ \\
\hline MIDs & 0.369 & $(0.321)$ & 0.069 & $(0.072)$ & $0.147^{*}$ & $(0.084)$ & 0.406 & $(0.437)$ \\
\hline Threat Environment & $-2.150^{* *}$ & $(0.876)$ & 0.183 & $(0.618)$ & 0.207 & $(0.696)$ & $-1.805^{*}$ & $(0.959)$ \\
\hline \# Border States & -0.020 & $(0.067)$ & $0.108^{* *}$ & $(0.044)$ & -0.005 & $(0.025)$ & -0.144 & $(0.093)$ \\
\hline Constant & 1.749 & $(2.245)$ & $2.875^{* *}$ & $(1.199)$ & 0.602 & $(1.855)$ & 0.915 & $(2.685)$ \\
\hline$R^{2}$ & 0.148 & & 0.312 & & 0.354 & & 0.179 & \\
\hline Prob $>\chi^{2}$ & 0.000 & & 0.000 & & 0.000 & & 0.000 & \\
\hline Observations & 1869 & & 333 & & 208 & & 1328 & \\
\hline
\end{tabular}

Panel-corrected standard errors in parentheses. Two-tailed significance tests used.

$* \mathrm{p} \leq 0.10 ; * * \mathrm{p} \leq 0.05 ; * * * \mathrm{p} \leq 0.01$

(1)

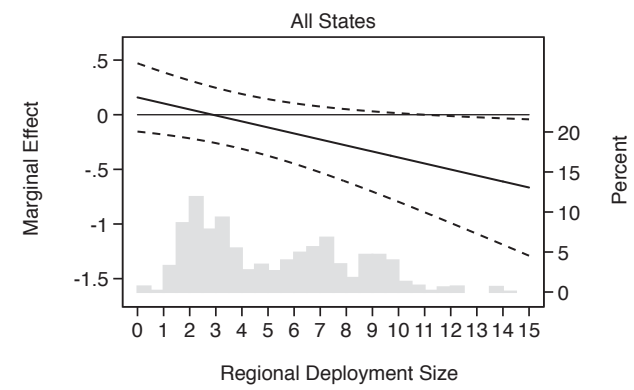

(3)

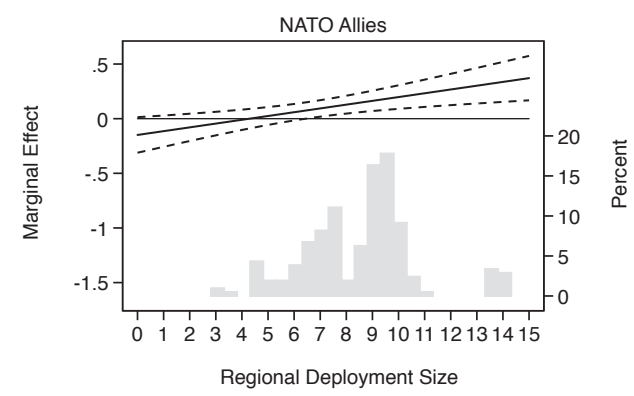

(2)

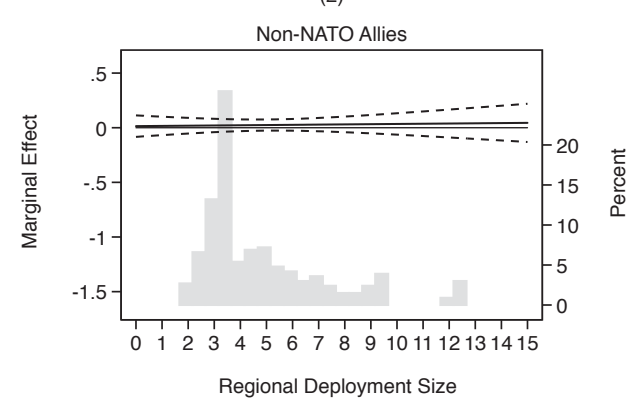

(4)

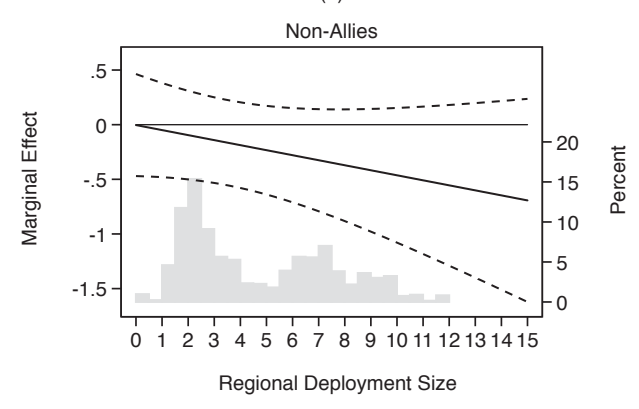

Figure A6: Marginal effect plot for pooled model and alliance sub-sample models. 95\% confidence intervals shown around coefficient point estimate. Models run on Post-Cold War years only (1991-2003). 
(1)

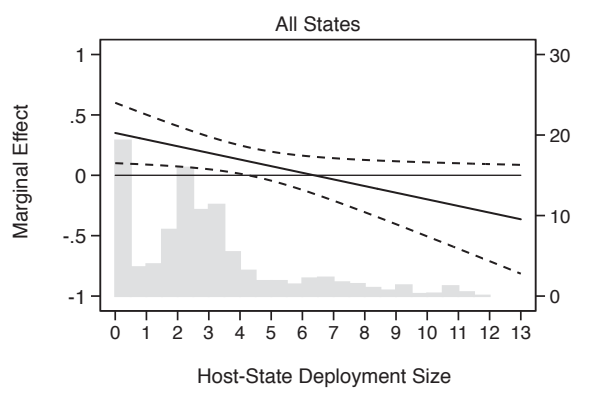

(3)

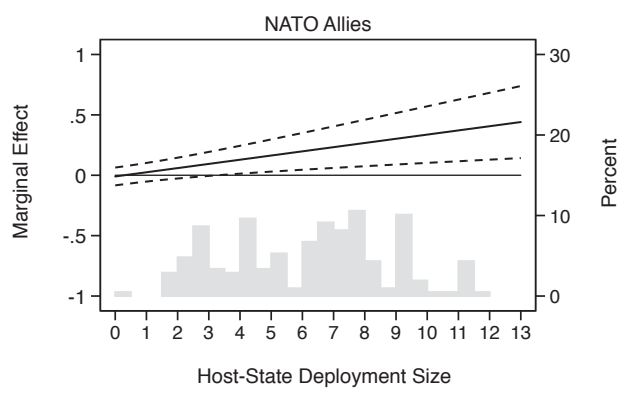

(2)

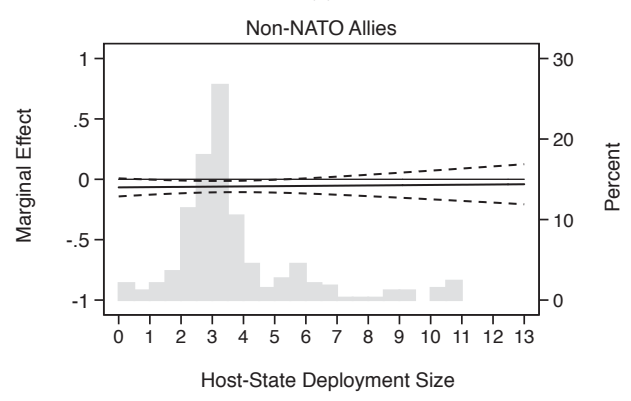

(4)

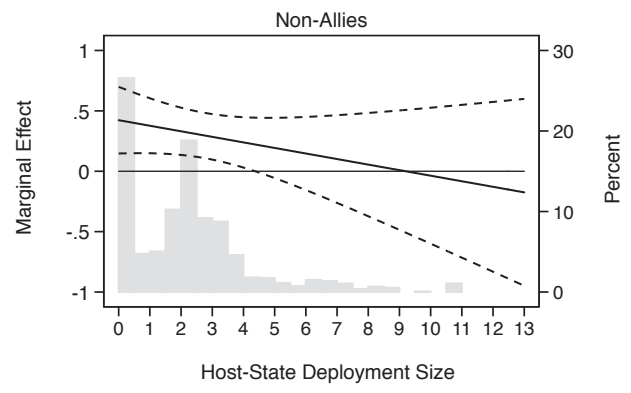

Figure A7: Marginal effect plot for pooled model and alliance sub-sample models. 95\% confidence intervals shown around coefficient point estimate. Models run on Post-Cold War years only (1991-2003).
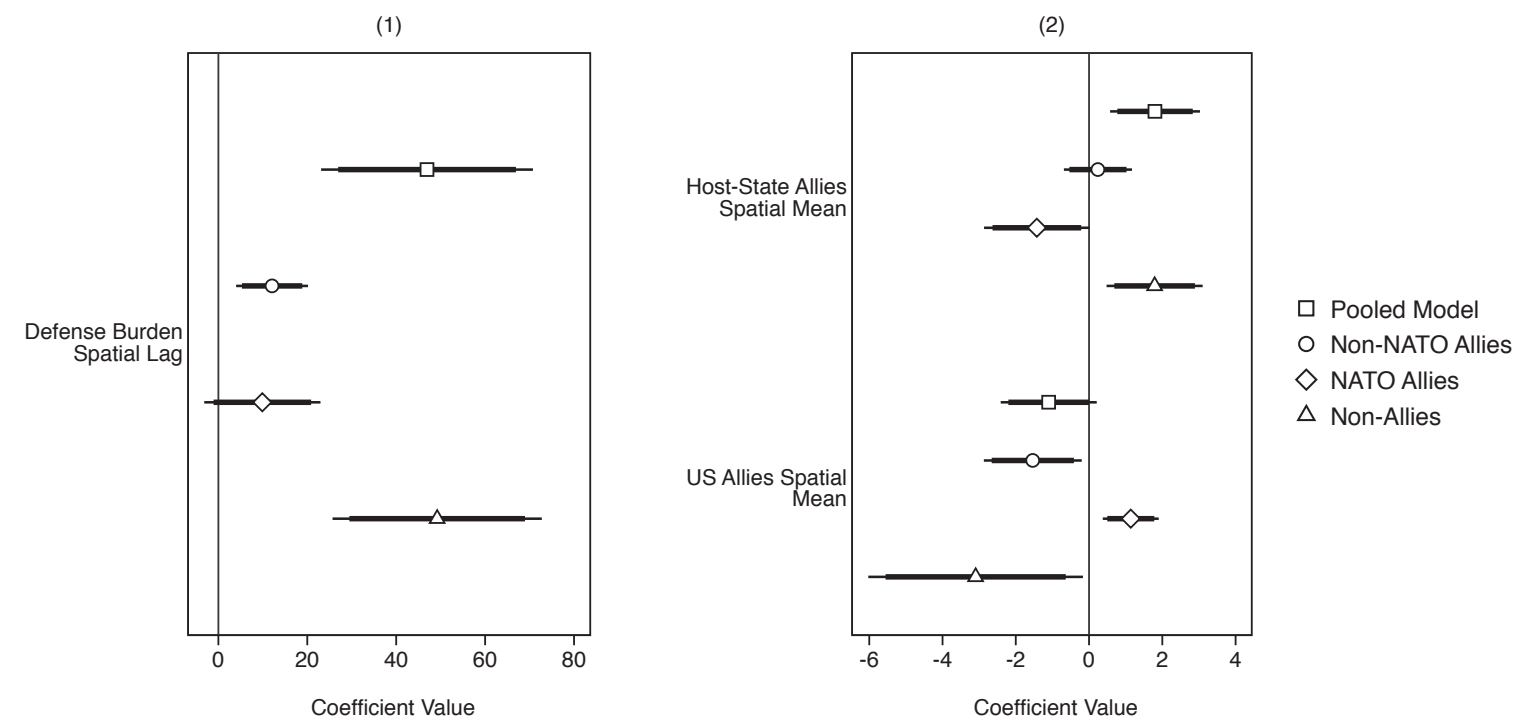

Figure A8: Coefficient plot for pooled model and alliance sub-sample models. 90\% and 95\% confidence intervals shown around coefficient point estimate. Models run on Post-Cold War years only (1991-2003). 
Table A4: US Troop Deployments and Host-State Defense Burdens. Models run on Pre-War on Terror years only (1950-2000).

\begin{tabular}{|c|c|c|c|c|c|c|c|c|}
\hline \multirow[b]{2}{*}{$\ln$ (Troops) } & \multicolumn{2}{|c|}{$\begin{array}{c}(1) \\
\text { All States }\end{array}$} & \multicolumn{2}{|c|}{$\begin{array}{c}(2) \\
\text { Non-NATO Allies }\end{array}$} & \multicolumn{2}{|c|}{$\begin{array}{c}(3) \\
\text { NATO Allies }\end{array}$} & \multicolumn{2}{|c|}{$\begin{array}{c}(4) \\
\text { Non-Allies }\end{array}$} \\
\hline & -0.005 & $(0.107)$ & 0.013 & $(0.049)$ & $-0.481^{* * *}$ & $(0.151)$ & -0.215 & $(0.169)$ \\
\hline ln (Troops Spatial Mean) & $0.593^{* * *}$ & $(0.086)$ & 0.060 & $(0.046)$ & $-0.336^{* * *}$ & $(0.120)$ & $0.695^{* * *}$ & $(0.103)$ \\
\hline Troops $\times$ Troops Spatial Mean & $-0.039^{* * *}$ & $(0.013)$ & -0.003 & $(0.008)$ & $0.058^{* * *}$ & $(0.015)$ & -0.028 & $(0.022)$ \\
\hline Spatial Lag & $17.840^{* * *}$ & $(2.992)$ & $0.896^{*}$ & $(0.541)$ & $8.993^{* * *}$ & $(3.124)$ & $25.651^{* * *}$ & $(3.917)$ \\
\hline Host-State Allies (Spatial Mean) & $2.300^{* * *}$ & $(0.496)$ & -0.399 & $(0.447)$ & 0.450 & $(0.360)$ & $2.677^{* * *}$ & $(0.606)$ \\
\hline US Allies (Spatial Mean) & $-2.221^{* * *}$ & $(0.520)$ & 0.081 & $(0.576)$ & $0.643^{* *}$ & $(0.301)$ & $-2.441^{* * *}$ & $(0.875)$ \\
\hline Polity & $-0.090^{* * *}$ & $(0.014)$ & $-0.018^{* * *}$ & $(0.006)$ & $-0.029^{*}$ & $(0.016)$ & $-0.125^{* * *}$ & $(0.019)$ \\
\hline Growth & -0.005 & $(0.008)$ & -0.001 & $(0.003)$ & 0.001 & $(0.005)$ & -0.005 & $(0.009)$ \\
\hline $\ln$ (Population) & -0.052 & $(0.148)$ & -0.076 & $(0.102)$ & $0.313^{* * *}$ & $(0.076)$ & -0.027 & $(0.171)$ \\
\hline Infant Mortality Rate & $-0.008^{*}$ & $(0.004)$ & -0.001 & $(0.001)$ & 0.005 & $(0.004)$ & $-0.009^{*}$ & $(0.005)$ \\
\hline Interstate War & $1.484^{* * *}$ & $(0.345)$ & $0.288^{*}$ & $(0.162)$ & $0.212^{*}$ & $(0.116)$ & $2.297^{* * *}$ & $(0.543)$ \\
\hline Civil War & $0.668^{* *}$ & $(0.306)$ & 0.005 & $(0.081)$ & 0.074 & $(0.121)$ & $0.855^{* *}$ & $(0.397)$ \\
\hline MIDs & 0.147 & $(0.136)$ & $0.150^{*}$ & $(0.078)$ & 0.058 & $(0.055)$ & 0.183 & $(0.168)$ \\
\hline Threat Environment & $-3.191^{* * *}$ & $(0.874)$ & $-1.150^{* *}$ & $(0.531)$ & -1.077 & $(0.736)$ & $-2.583^{*}$ & $(1.393)$ \\
\hline \# Border States & $0.147^{*}$ & $(0.084)$ & 0.042 & $(0.050)$ & 0.006 & $(0.038)$ & 0.079 & $(0.105)$ \\
\hline Constant & 1.397 & $(1.461)$ & $2.451^{* *}$ & $(1.044)$ & 2.259 & $(1.534)$ & 0.762 & $(1.730)$ \\
\hline$R^{2}$ & 0.087 & & 0.109 & & 0.312 & & 0.107 & \\
\hline Prob $>\chi^{2}$ & 0.000 & & 0.000 & & 0.000 & & 0.000 & \\
\hline Observations & 5607 & & 1195 & & 663 & & 3749 & \\
\hline
\end{tabular}

\footnotetext{
Panel-corrected standard errors in parentheses. Two-tailed significance tests used.
}

$* \mathrm{p} \leq 0.10 ; * * \mathrm{p} \leq 0.05 ; * * * \mathrm{p} \leq 0.01$

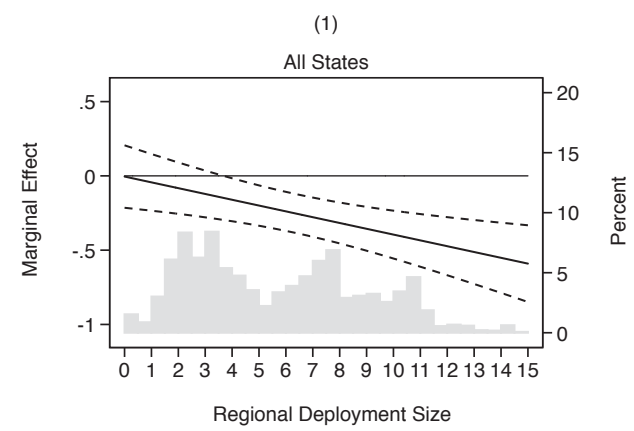

(3)

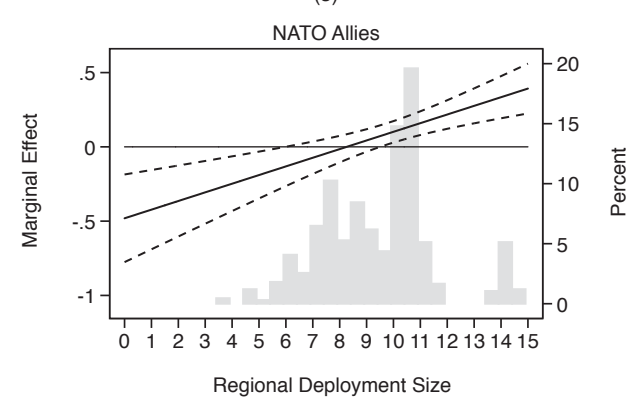

(2)

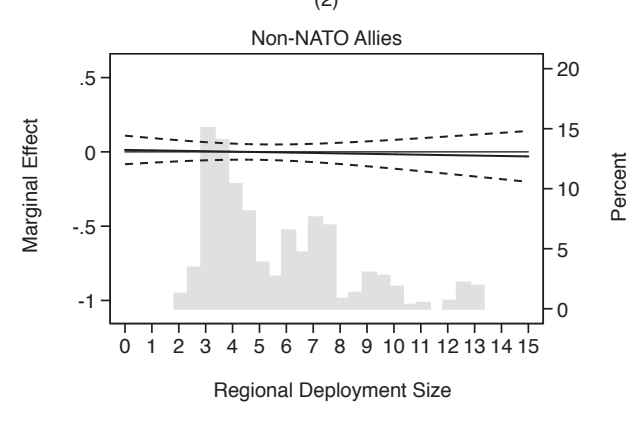

(4)

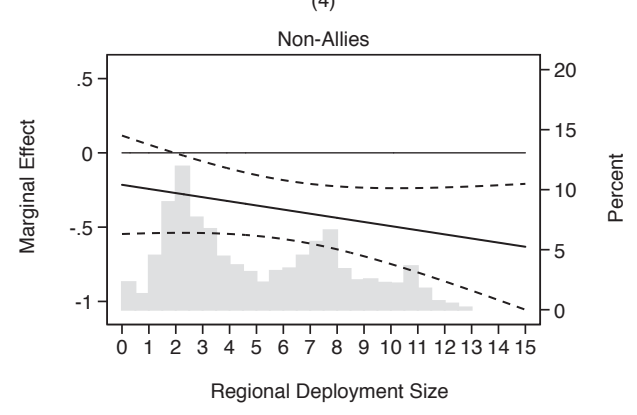

Figure A9: Marginal effect plot for pooled model and alliance sub-sample models. 95\% confidence intervals shown around coefficient point estimate. Models cover only 1950-2000 to exclude years associated with the War on Terror. 
(1)

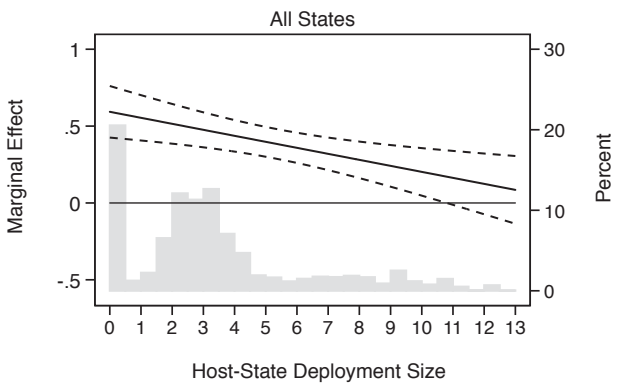

(3)

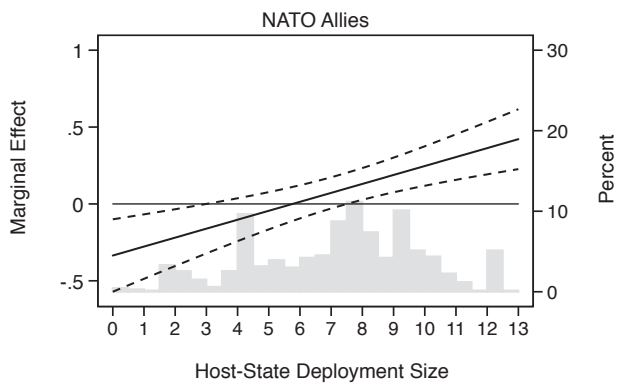

(2)

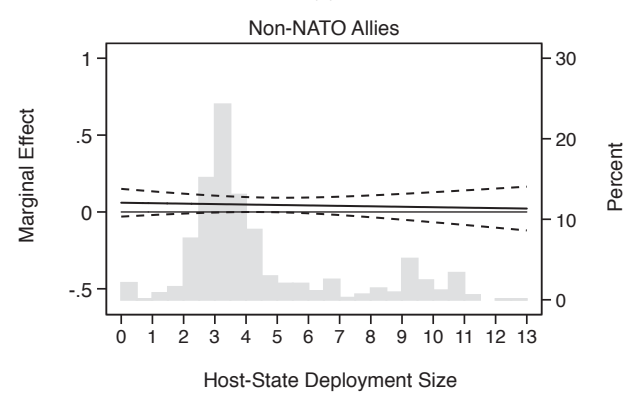

(4)

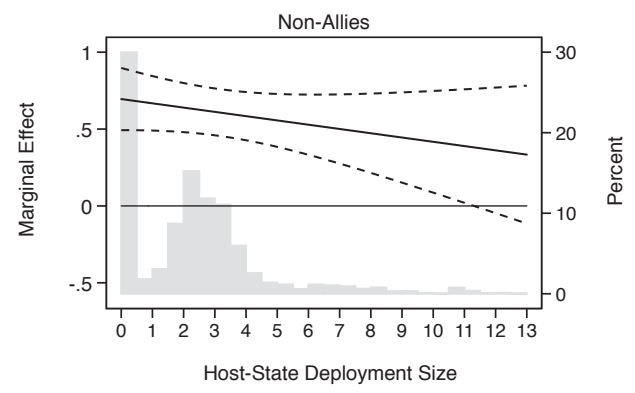

Figure A10: Marginal effect plot for pooled model and alliance sub-sample models. 95\% confidence intervals shown around coefficient point estimate. Models cover only 1950-2000 to exclude years associated with the War on Terror.

Table A5: US Troop Deployments and Host-State Defense Burdens. Includes Spatial MIDs variable for referent state regional conflict.

\begin{tabular}{lcccccccc}
\hline & \multicolumn{3}{c}{$(1)$} & \multicolumn{2}{c}{$(2)$} & \multicolumn{2}{c}{$(3)$} & \multicolumn{2}{c}{$(4)$} \\
& \multicolumn{2}{c}{ All States } & Non-NATO Allies & NATO Allies & \multicolumn{2}{c}{ Non-Allies } \\
\hline ln (Troops) & 0.027 & $(0.098)$ & 0.020 & $(0.046)$ & -0.152 & $(0.132)$ & -0.157 & $(0.160)$ \\
ln (Troops Spatial Mean) & $0.558^{* * *}$ & $(0.078)$ & 0.062 & $(0.044)$ & -0.093 & $(0.099)$ & $0.657^{* * *}$ & $(0.095)$ \\
Troops $~ T$ Troops Spatial Mean & $-0.039^{* * *}$ & $(0.012)$ & -0.003 & $(0.008)$ & $0.026^{*}$ & $(0.014)$ & -0.032 & $(0.021)$ \\
Spatial Lag & $17.909^{* * *}$ & $(2.940)$ & $0.950^{*}$ & $(0.538)$ & $9.871^{* * *}$ & $(2.992)$ & $25.758^{* * *}$ & $(3.836)$ \\
Host-State Allies (Spatial Mean) & $2.033^{* * *}$ & $(0.441)$ & -0.395 & $(0.436)$ & $0.593^{*}$ & $(0.332)$ & $2.285^{* * *}$ & $(0.520)$ \\
US Allies (Spatial Mean) & $-1.925^{* * *}$ & $(0.475)$ & -0.014 & $(0.559)$ & $0.541^{*}$ & $(0.292)$ & $-2.244^{* * *}$ & $(0.842)$ \\
Polity & $-0.091^{* * *}$ & $(0.013)$ & $-0.019^{* * *}$ & $(0.006)$ & $-0.029^{*}$ & $(0.016)$ & $-0.125^{* * *}$ & $(0.018)$ \\
Growth & -0.005 & $(0.007)$ & -0.001 & $(0.003)$ & -0.000 & $(0.005)$ & -0.005 & $(0.008)$ \\
ln (Population) & -0.079 & $(0.140)$ & -0.076 & $(0.097)$ & $0.329^{* * *}$ & $(0.071)$ & -0.065 & $(0.163)$ \\
Infant Mortality Rate & $-0.007^{*}$ & $(0.004)$ & -0.001 & $(0.001)$ & $0.007^{* *}$ & $(0.003)$ & $-0.009^{*}$ & $(0.005)$ \\
Interstate War & $1.401^{* * *}$ & $(0.319)$ & $0.256^{*}$ & $(0.143)$ & 0.159 & $(0.102)$ & $2.278^{* * *}$ & $(0.526)$ \\
Civil War & $0.684^{* *}$ & $(0.286)$ & 0.000 & $(0.076)$ & 0.092 & $(0.114)$ & $0.860^{* *}$ & $(0.371)$ \\
MIDs & 0.103 & $(0.125)$ & $0.147^{*}$ & $(0.079)$ & 0.059 & $(0.046)$ & 0.134 & $(0.158)$ \\
MIDs (Spatial Mean) & 0.020 & $(0.034)$ & -0.009 & $(0.018)$ & $-0.023^{*}$ & $(0.012)$ & 0.029 & $(0.043)$ \\
Threat Environment & $-3.271^{* * *}$ & $(0.827)$ & $-1.038^{* *}$ & $(0.526)$ & $-1.107^{*}$ & $(0.660)$ & $-2.873^{* *}$ & $(1.293)$ \\
$\#$ Border States & $0.137^{*}$ & $(0.080)$ & 0.040 & $(0.049)$ & -0.006 & $(0.035)$ & 0.071 & $(0.102)$ \\
Constant & 1.660 & $(1.376)$ & $2.392^{* *}$ & $(0.985)$ & -0.345 & $(1.316)$ & 1.165 & $(1.638)$ \\
\hline$R^{2}$ & 0.084 & & 0.106 & & 0.300 & & 0.105 & \\
Prob > $\chi^{2}$ & 0.000 & & 0.000 & & 0.000 & & 0.000 & 4058 \\
Observations & 6052 & & 1273 & & 721 & & &
\end{tabular}

Panel-corrected standard errors in parentheses. Two-tailed significance tests used.

$* \mathrm{p} \leq 0.10 ; * * \mathrm{p} \leq 0.05 ; * * * \mathrm{p} \leq 0.01$ 
(1)

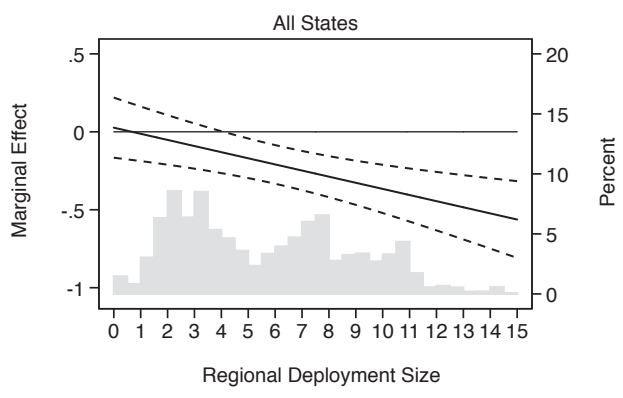

(3)

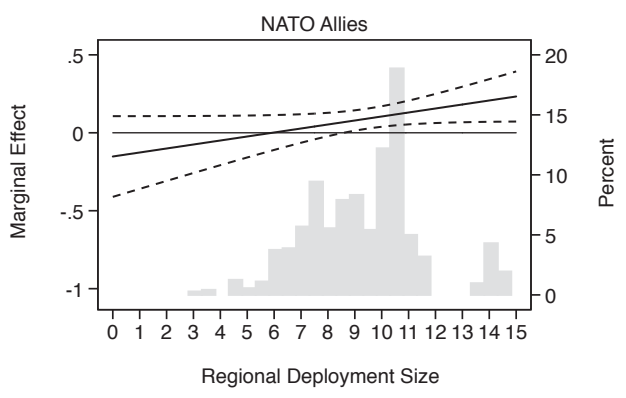

(2)

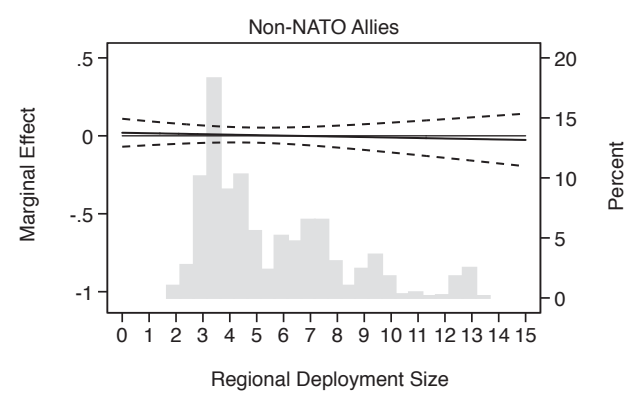

(4)

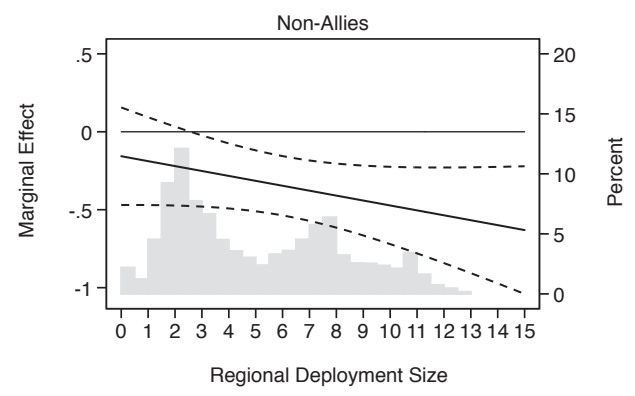

Figure A11: Marginal effect plot for pooled model and alliance sub-sample models. 95\% confidence intervals shown around coefficient point estimate. Models include spatial MIDs variable. 

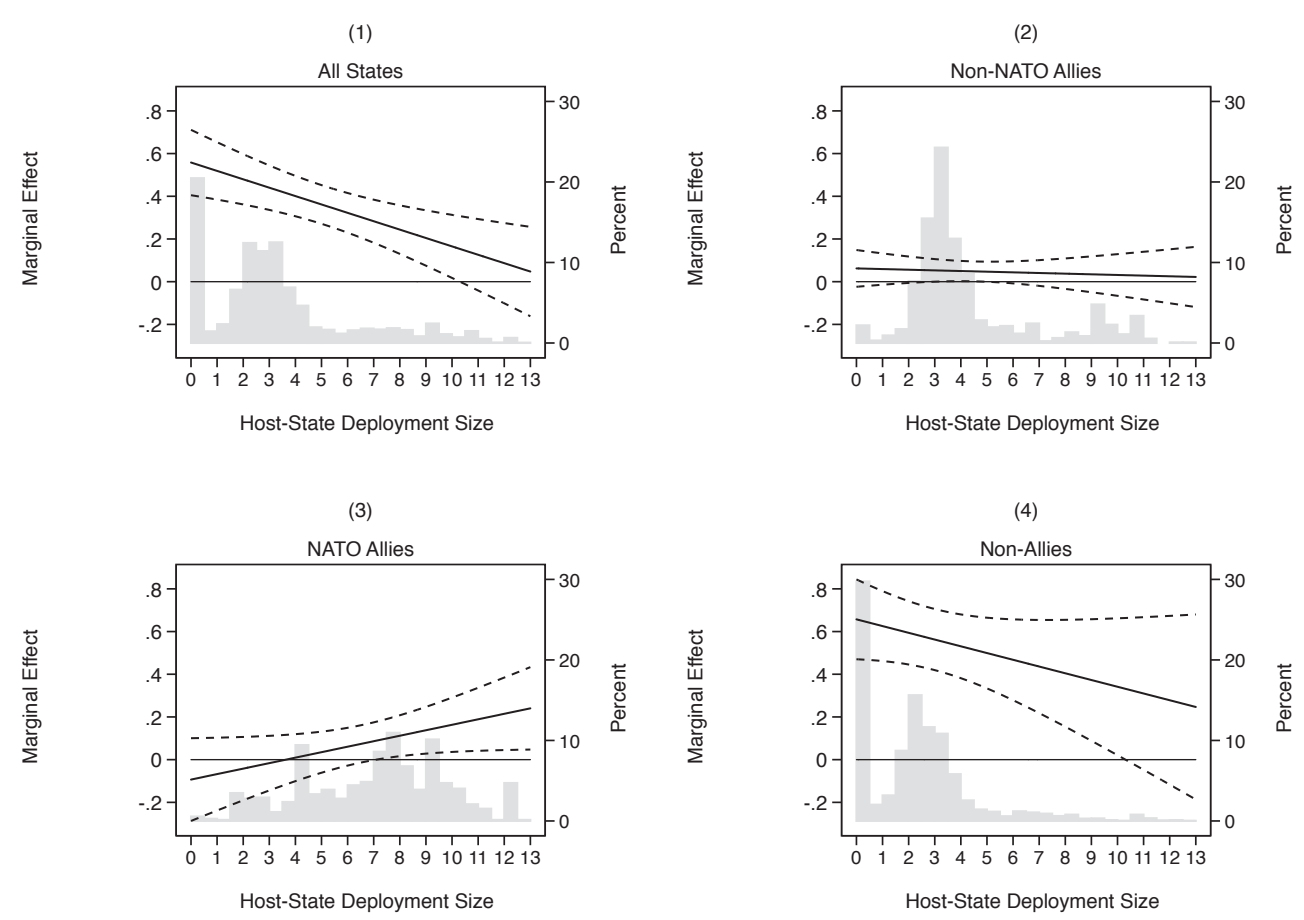

Figure A12: Marginal effect plot for pooled model and alliance sub-sample models. 95\% confidence intervals shown around coefficient point estimate. Models include spatial MIDs variable.

Table A6: US Troop Deployments and Host-State Defense Burdens. Deployments below 20 are counted as 0 .

\begin{tabular}{|c|c|c|c|c|c|c|c|c|}
\hline \multirow{2}{*}{ ln(Troops) } & \multicolumn{2}{|c|}{$\begin{array}{c}(1) \\
\text { All States }\end{array}$} & \multicolumn{2}{|c|}{$\begin{array}{c}(2) \\
\text { Non-NATO Allies }\end{array}$} & \multicolumn{2}{|c|}{$\begin{array}{c}(3) \\
\text { NATO Allies }\end{array}$} & \multicolumn{2}{|c|}{$\begin{array}{c}(4) \\
\text { Non-Allies }\end{array}$} \\
\hline & 0.022 & $(0.054)$ & -0.003 & $(0.029)$ & -0.158 & $(0.109)$ & -0.140 & $(0.098)$ \\
\hline $\ln$ (Troops Spatial Mean) & $0.421^{* * *}$ & $(0.056)$ & 0.045 & $(0.032)$ & -0.087 & $(0.082)$ & $0.485^{* * *}$ & $(0.066)$ \\
\hline Troops $\times$ Troops Spatial Mean & $-0.024^{* * *}$ & $(0.008)$ & 0.000 & $(0.006)$ & $0.028^{* *}$ & $(0.011)$ & -0.011 & $(0.012)$ \\
\hline Spatial Lag & $18.083^{* * *}$ & $(2.898)$ & 0.874 & $(0.534)$ & $9.875^{* * *}$ & $(2.967)$ & $26.393^{* * *}$ & $(3.763)$ \\
\hline Host-State Allies (Spatial Mean) & $2.022^{* * *}$ & $(0.446)$ & -0.377 & $(0.430)$ & 0.503 & $(0.331)$ & $2.346^{* * *}$ & $(0.531)$ \\
\hline US Allies (Spatial Mean) & $-1.911^{* * *}$ & $(0.478)$ & -0.038 & $(0.559)$ & $0.708^{* *}$ & $(0.281)$ & $-1.810^{* *}$ & $(0.814)$ \\
\hline Polity & $-0.094^{* * *}$ & $(0.014)$ & $-0.018^{* * *}$ & $(0.005)$ & $-0.033^{* *}$ & $(0.016)$ & $-0.129^{* * *}$ & $(0.019)$ \\
\hline Growth & -0.005 & $(0.007)$ & -0.001 & $(0.003)$ & 0.001 & $(0.005)$ & -0.005 & $(0.008)$ \\
\hline $\ln$ (Population) & -0.119 & $(0.133)$ & -0.076 & $(0.099)$ & $0.267^{* * *}$ & $(0.070)$ & -0.119 & $(0.155)$ \\
\hline Infant Mortality Rate & $-0.008^{*}$ & $(0.004)$ & -0.001 & $(0.001)$ & $0.006^{*}$ & $(0.003)$ & $-0.009^{* *}$ & $(0.005)$ \\
\hline Interstate War & $1.413^{* * *}$ & $(0.320)$ & $0.253^{*}$ & $(0.143)$ & $0.187^{*}$ & $(0.110)$ & $2.324^{* * *}$ & $(0.530)$ \\
\hline Civil War & $0.680^{* *}$ & $(0.286)$ & -0.001 & $(0.075)$ & 0.107 & $(0.119)$ & $0.846^{* *}$ & $(0.371)$ \\
\hline MIDs & 0.140 & $(0.128)$ & $0.131^{*}$ & $(0.072)$ & 0.022 & $(0.052)$ & 0.207 & $(0.161)$ \\
\hline Threat Environment & $-3.503^{* * *}$ & $(0.842)$ & $-1.005^{*}$ & $(0.529)$ & -0.951 & $(0.627)$ & $-3.098^{* *}$ & $(1.288)$ \\
\hline \# Border States & $0.144^{*}$ & $(0.081)$ & 0.041 & $(0.050)$ & 0.000 & $(0.031)$ & 0.081 & $(0.102)$ \\
\hline Constant & $2.578^{*}$ & $(1.341)$ & $2.471^{* *}$ & $(0.985)$ & -0.103 & $(1.172)$ & 2.158 & $(1.573)$ \\
\hline$R^{2}$ & 0.081 & & 0.103 & & 0.316 & & 0.101 & \\
\hline Prob $>\chi^{2}$ & 0.000 & & 0.000 & & 0.000 & & 0.000 & \\
\hline Observations & 6052 & & 1273 & & 721 & & 4058 & \\
\hline
\end{tabular}

Panel-corrected standard errors in parentheses. Two-tailed significance tests used.

$* \mathrm{p} \leq 0.10 ; * * \mathrm{p} \leq 0.05 ; * * * \mathrm{p} \leq 0.01$ 
(1)

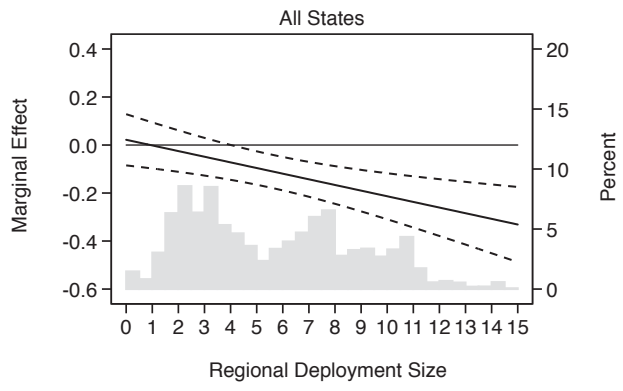

(3)

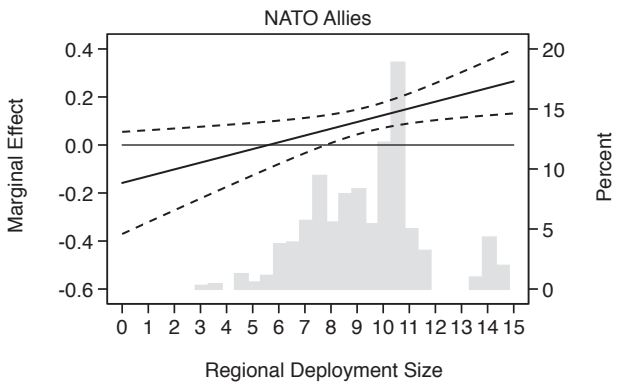

(2)

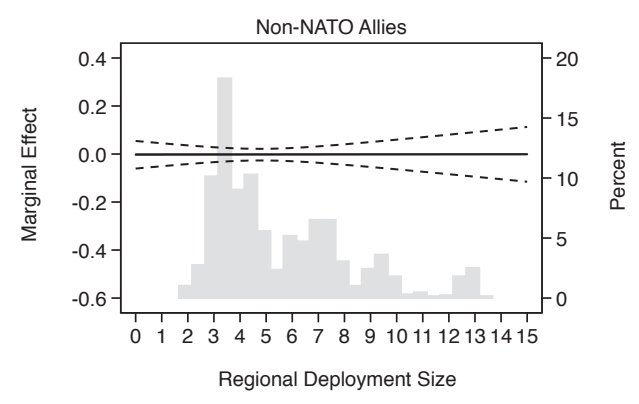

(4)

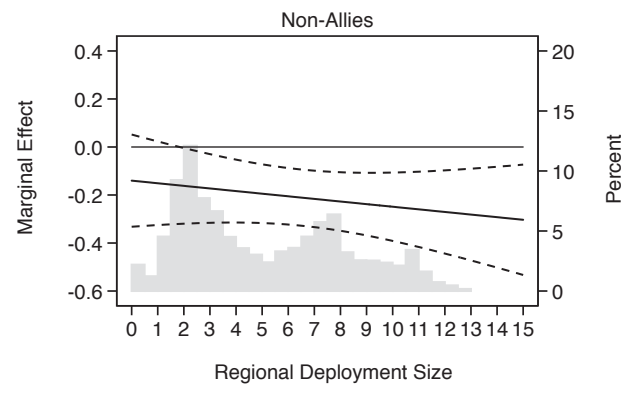

Figure A13: Marginal effect plot for pooled model and alliance sub-sample models. 95\% confidence intervals shown around coefficient point estimate. Deployments below 20 are counted as 0 . 
(1)

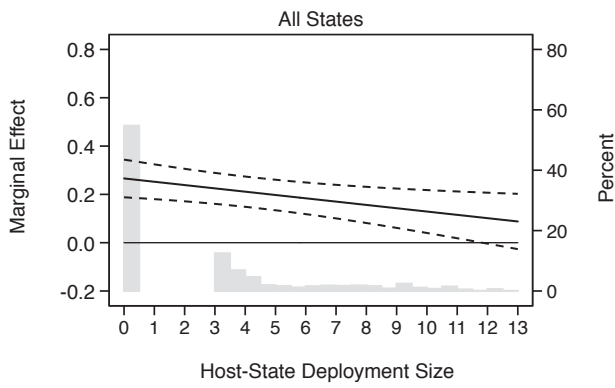

(3)

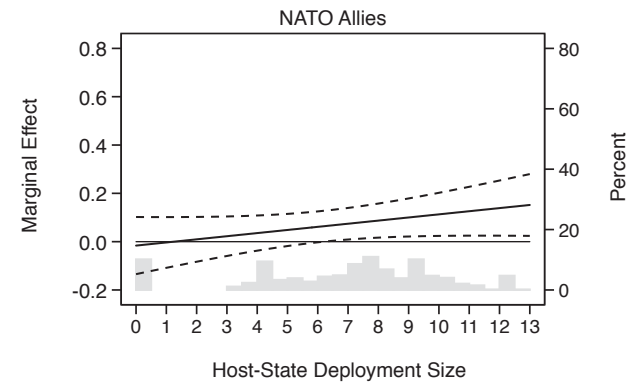

(2)

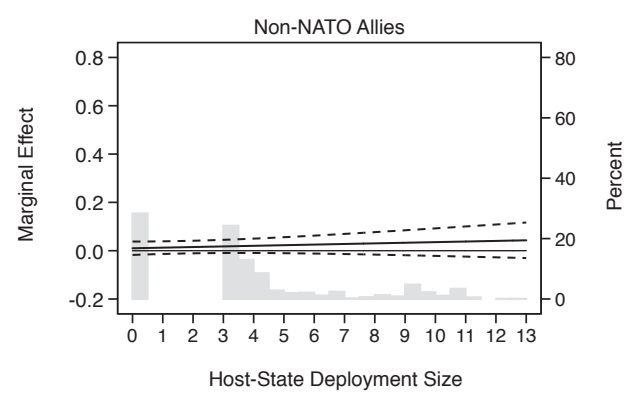

(4)

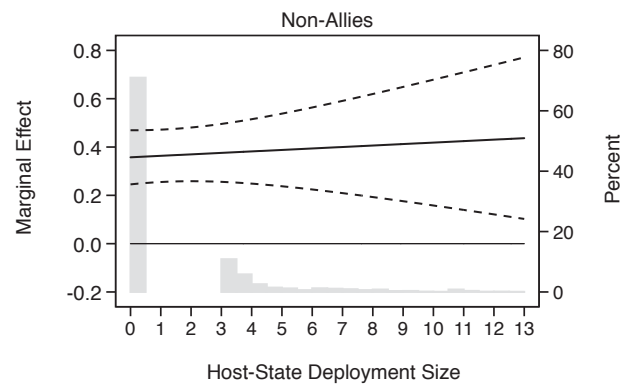

Figure A14: Marginal effect plot for pooled model and alliance sub-sample models. 95\% confidence intervals shown around coefficient point estimate. Deployments below 20 are counted as 0 .

Table A7: US Troop Deployments and Host-State Defense Burdens. Deployments below 100 are counted as 0.

\begin{tabular}{|c|c|c|c|c|c|c|c|c|}
\hline \multirow{2}{*}{$\begin{array}{l}\ln (\text { Troops }) \\
\end{array}$} & \multicolumn{2}{|c|}{$\begin{array}{c}(1) \\
\text { All States }\end{array}$} & \multicolumn{2}{|c|}{$\begin{array}{c}(2) \\
\text { Non-NATO Allies }\end{array}$} & \multicolumn{2}{|c|}{$\begin{array}{c}(3) \\
\text { NATO Allies }\end{array}$} & \multicolumn{2}{|c|}{$\begin{array}{c}(4) \\
\text { Non-Allies }\end{array}$} \\
\hline & -0.049 & $(0.046)$ & -0.011 & $(0.019)$ & -0.080 & $(0.078)$ & $-0.368^{* * *}$ & $(0.130)$ \\
\hline $\ln$ (Troops Spatial Mean) & $0.266^{* * *}$ & $(0.040)$ & 0.010 & $(0.014)$ & -0.016 & $(0.060)$ & $0.357^{* * *}$ & $(0.057)$ \\
\hline Troops $\times$ Troops Spatial Mean & $-0.014^{* *}$ & $(0.006)$ & 0.003 & $(0.003)$ & 0.013 & $(0.008)$ & 0.006 & $(0.014)$ \\
\hline Spatial Lag & $18.594^{* * *}$ & $(2.950)$ & $0.893^{*}$ & $(0.540)$ & $9.989^{* * *}$ & $(3.016)$ & $26.443^{* * *}$ & $(3.837)$ \\
\hline Host-State Allies (Spatial Mean) & $1.958^{* * *}$ & $(0.450)$ & -0.366 & $(0.432)$ & $0.683^{* *}$ & $(0.323)$ & $2.314^{* * *}$ & $(0.529)$ \\
\hline US Allies (Spatial Mean) & $-1.699^{* * *}$ & $(0.465)$ & -0.054 & $(0.557)$ & $0.593^{* *}$ & $(0.289)$ & $-1.356^{*}$ & $(0.816)$ \\
\hline Polity & $-0.092^{* * *}$ & $(0.014)$ & $-0.019^{* * *}$ & $(0.006)$ & $-0.032^{*}$ & $(0.017)$ & $-0.128^{* * *}$ & $(0.019)$ \\
\hline Growth & -0.005 & $(0.007)$ & -0.001 & $(0.003)$ & 0.001 & $(0.005)$ & -0.005 & $(0.008)$ \\
\hline $\ln$ (Population) & -0.082 & $(0.129)$ & -0.057 & $(0.096)$ & $0.392^{* * *}$ & $(0.063)$ & -0.093 & $(0.153)$ \\
\hline Infant Mortality Rate & $-0.008^{* *}$ & $(0.004)$ & -0.001 & $(0.001)$ & $0.007^{*}$ & $(0.004)$ & $-0.009^{*}$ & $(0.005)$ \\
\hline Interstate War & $1.407^{* * *}$ & $(0.320)$ & $0.249^{*}$ & $(0.144)$ & 0.159 & $(0.105)$ & $2.304^{* * *}$ & $(0.526)$ \\
\hline Civil War & $0.677^{* *}$ & $(0.288)$ & -0.000 & $(0.076)$ & 0.089 & $(0.114)$ & $0.844^{* *}$ & $(0.374)$ \\
\hline MIDs & 0.140 & $(0.128)$ & $0.130^{*}$ & $(0.073)$ & 0.008 & $(0.053)$ & 0.178 & $(0.162)$ \\
\hline Threat Environment & $-3.610^{* * *}$ & $(0.857)$ & $-0.953^{*}$ & $(0.520)$ & -0.987 & $(0.656)$ & $-3.282^{* *}$ & $(1.316)$ \\
\hline \# Border States & 0.125 & $(0.081)$ & 0.022 & $(0.049)$ & -0.027 & $(0.033)$ & 0.064 & $(0.103)$ \\
\hline Constant & $3.216^{* *}$ & $(1.311)$ & $2.502^{* * *}$ & $(0.971)$ & -1.478 & $(1.045)$ & $2.786^{*}$ & $(1.567)$ \\
\hline$R^{2}$ & 0.077 & & 0.104 & & 0.280 & & 0.098 & \\
\hline Prob $>\chi^{2}$ & 0.000 & & 0.000 & & 0.000 & & 0.000 & \\
\hline Observations & 6052 & & 1273 & & 721 & & 4058 & \\
\hline
\end{tabular}

Panel-corrected standard errors in parentheses. Two-tailed significance tests used.

$* \mathrm{p} \leq 0.10 ; * * \mathrm{p} \leq 0.05 ; * * * \mathrm{p} \leq 0.01$ 
(1)

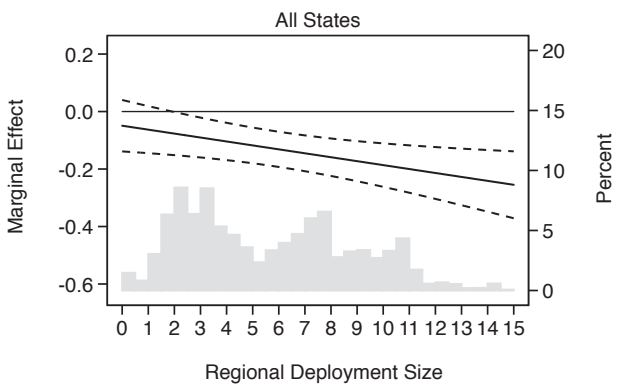

(3)

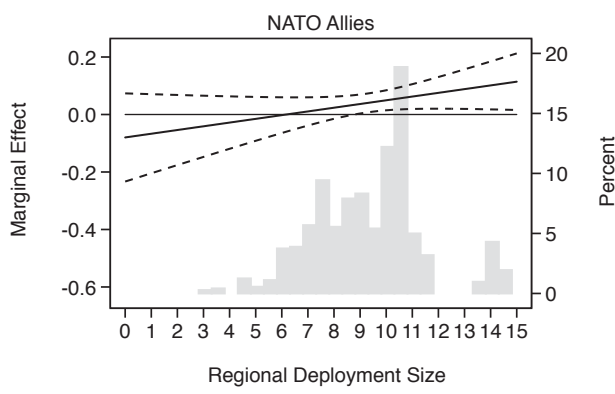

(2)

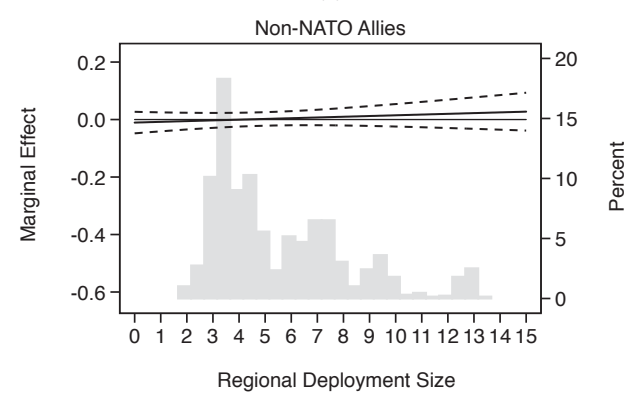

(4)

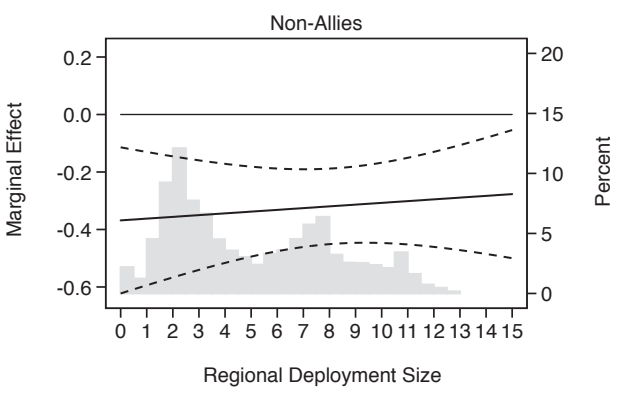

Figure A15: Marginal effect plot for pooled model and alliance sub-sample models. 95\% confidence intervals shown around coefficient point estimate. Deployments below 100 are counted as 0 . 
(1)

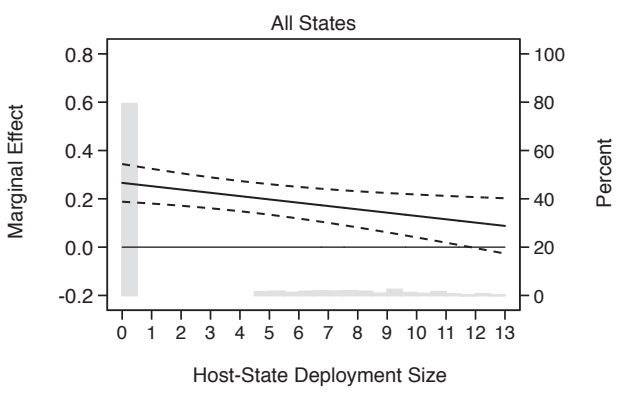

(3)

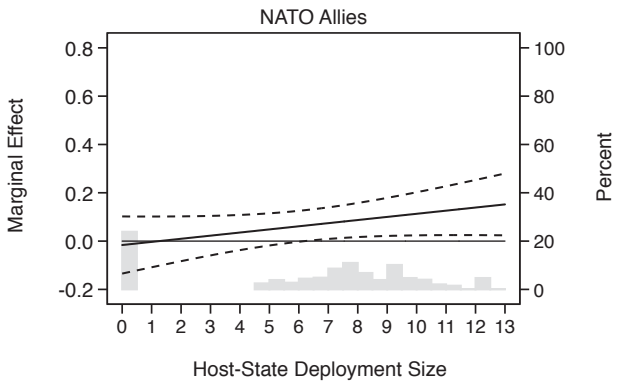

(2)

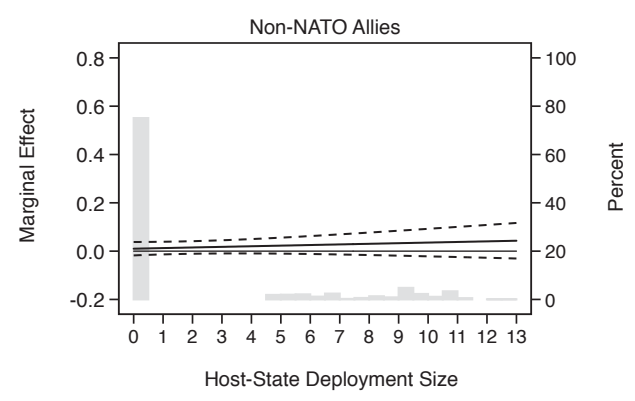

(4)

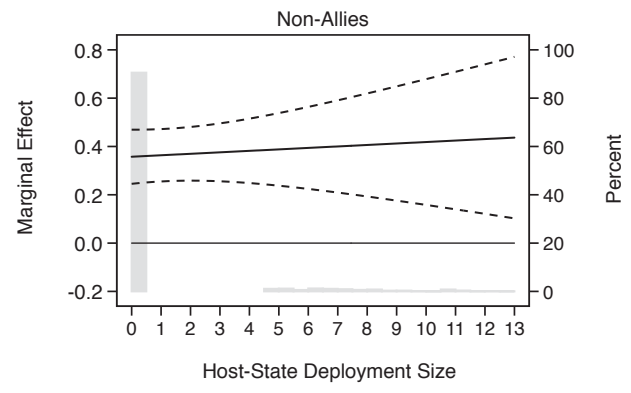

Figure A16: Marginal effect plot for pooled model and alliance sub-sample models. 95\% confidence intervals shown around coefficient point estimate. Deployments below 100 are counted as 0 .

Table A8: US Troop Deployments and Host-State Defense Burdens. Subsamples based on UN voting absolute ideal point distance percentiles.

\begin{tabular}{|c|c|c|c|c|c|c|c|c|}
\hline \multirow[b]{2}{*}{$\ln$ (Troops) } & \multicolumn{2}{|c|}{$\begin{array}{c}(1) \\
<25^{t h}\end{array}$} & \multicolumn{2}{|c|}{$25^{t h}(2)-50^{t h}$} & \multicolumn{2}{|c|}{$(3)$} & \multicolumn{2}{|c|}{$\begin{array}{c}(4) \\
>75^{t h}\end{array}$} \\
\hline & $0.099^{*}$ & $(0.059)$ & $0.129^{* *}$ & $(0.061)$ & 0.225 & $(0.161)$ & -0.025 & $(0.220)$ \\
\hline ln (Troops Spatial Mean) & $0.090^{* *}$ & $(0.044)$ & $0.160^{* * *}$ & $(0.040)$ & $0.445^{* * *}$ & $(0.095)$ & $0.951^{* * *}$ & $(0.149)$ \\
\hline $\ln ($ Troops $) \times \ln ($ Troops Spatial Mean $)$ & -0.003 & $(0.007)$ & $-0.026^{* * *}$ & $(0.008)$ & $-0.071^{* * *}$ & $(0.024)$ & $-0.055^{* *}$ & $(0.022)$ \\
\hline Spatial Lag & 1.129 & $(0.804)$ & $20.883^{* * *}$ & $(2.825)$ & $21.790^{* * *}$ & $(5.830)$ & $19.541^{* * *}$ & $(4.320)$ \\
\hline Host-State Allies (Spatial Mean) & $0.794^{* * *}$ & $(0.250)$ & $1.981^{* * *}$ & $(0.296)$ & $1.090^{* * *}$ & $(0.364)$ & $3.232^{* * *}$ & $(0.807)$ \\
\hline US Allies (Spatial Mean) & -0.386 & $(0.239)$ & $-0.841^{* * *}$ & $(0.288)$ & $-1.355^{* * *}$ & $(0.471)$ & $-2.059^{* *}$ & $(0.955)$ \\
\hline Polity & 0.015 & $(0.012)$ & $-0.045^{* * *}$ & $(0.011)$ & $-0.089^{* * *}$ & $(0.014)$ & $-0.170^{* * *}$ & $(0.026)$ \\
\hline Growth & -0.002 & $(0.005)$ & 0.002 & $(0.004)$ & -0.004 & $(0.006)$ & 0.028 & $(0.027)$ \\
\hline ln (Population) & -0.012 & $(0.086)$ & $-0.210^{* * *}$ & $(0.080)$ & $-0.281^{* * *}$ & $(0.087)$ & $-0.532^{* *}$ & $(0.228)$ \\
\hline Infant Mortality Rate & -0.003 & $(0.002)$ & $-0.008^{* * *}$ & $(0.002)$ & $-0.011^{* * *}$ & $(0.003)$ & -0.009 & $(0.010)$ \\
\hline Interstate War & $0.580^{* * *}$ & $(0.197)$ & -0.015 & $(0.268)$ & $1.094^{*}$ & $(0.570)$ & $3.691^{* * *}$ & $(0.889)$ \\
\hline Civil War & -0.046 & $(0.162)$ & 0.250 & $(0.189)$ & $0.730^{* *}$ & $(0.361)$ & $1.623^{* *}$ & $(0.640)$ \\
\hline MIDs & $0.217^{*}$ & $(0.128)$ & $0.407^{* * *}$ & $(0.095)$ & $0.583^{* * *}$ & $(0.201)$ & 0.212 & $(0.265)$ \\
\hline Threat Environment & $-2.129^{* * *}$ & $(0.647)$ & $-2.618^{* * *}$ & $(0.480)$ & -0.768 & $(0.886)$ & $-5.638^{* * *}$ & $(2.060)$ \\
\hline \# Border States & $0.095^{* *}$ & $(0.044)$ & $0.188^{* * *}$ & $(0.056)$ & $0.169^{* * *}$ & $(0.059)$ & 0.201 & $(0.135)$ \\
\hline Constant & $1.432^{*}$ & $(0.747)$ & $2.577^{* * *}$ & $(0.672)$ & $2.614^{* * *}$ & $(0.652)$ & $4.288^{*}$ & $(2.443)$ \\
\hline$R^{2}$ & 0.105 & & 0.272 & & 0.324 & & 0.135 & \\
\hline Prob $>\chi^{2}$ & 0.000 & & 0.000 & & 0.000 & & 0.000 & \\
\hline Observations & 1431 & & 1423 & & 1431 & & 1767 & \\
\hline
\end{tabular}

Panel-corrected standard errors in parentheses. Two-tailed significance tests used.

$* \mathrm{p} \leq 0.10 ; * * \mathrm{p} \leq 0.05 ; * * * \mathrm{p} \leq 0.01$ 
(1)

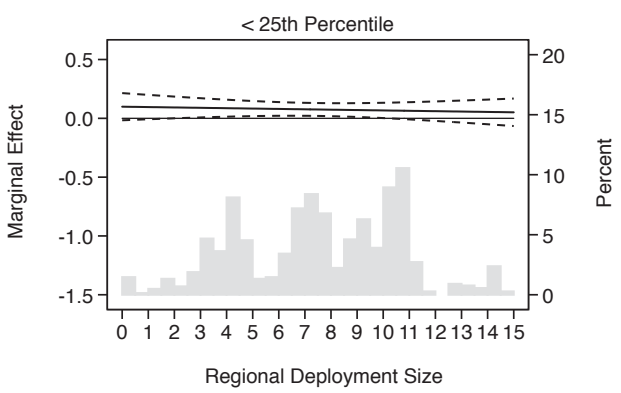

(3)

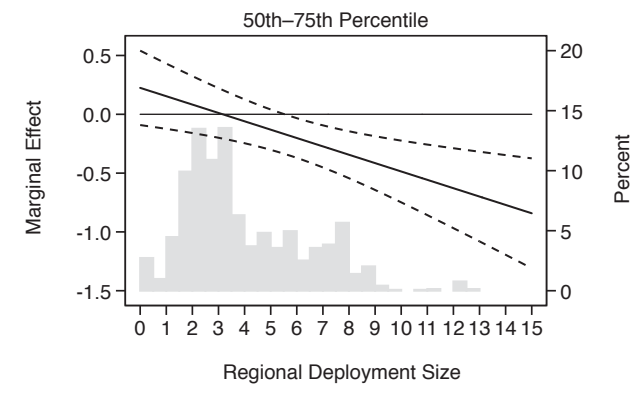

(2)

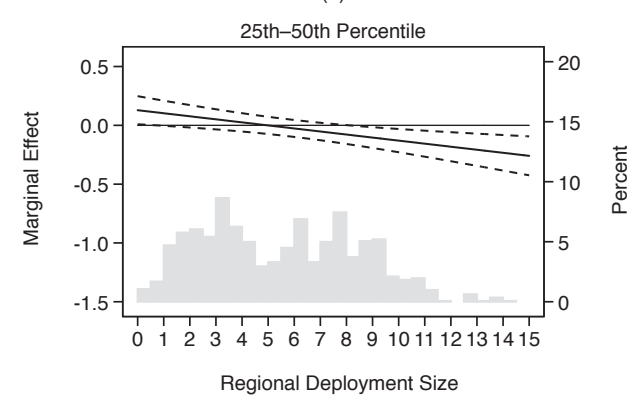

(4)

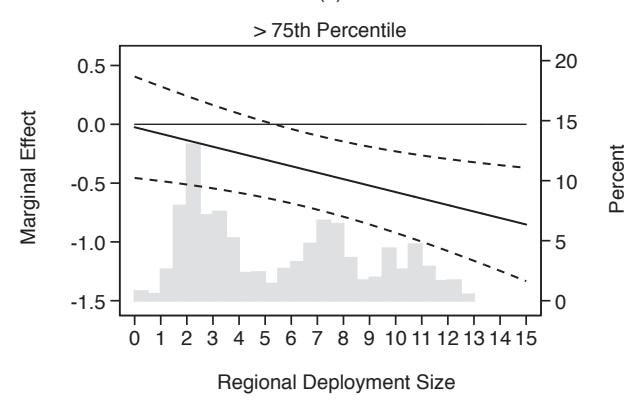

Figure A17: Marginal effect plot for pooled model and alliance sub-sample models. 95\% confidence intervals shown around coefficient point estimate. Panels show UN voting ideal point distance from the US in quartiles. 
(1)

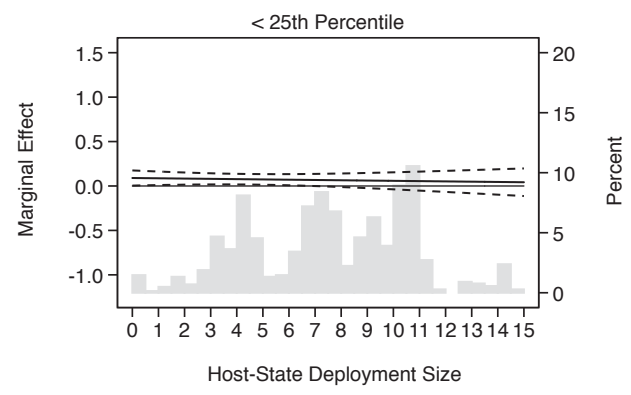

(3)

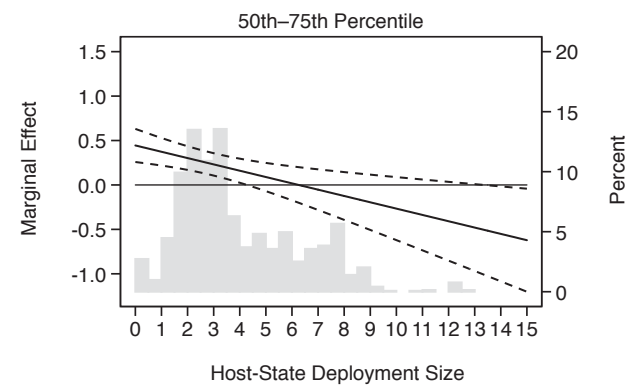

(2)

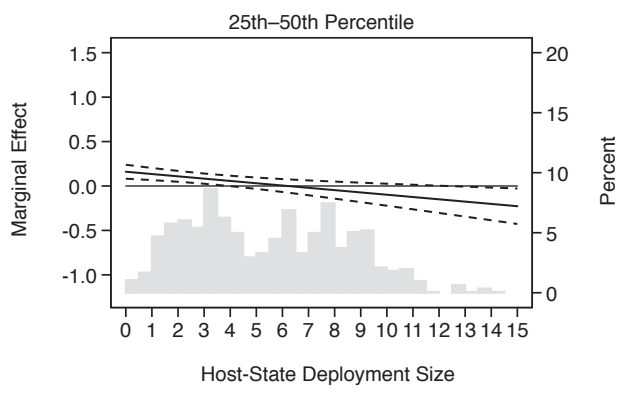

(4)

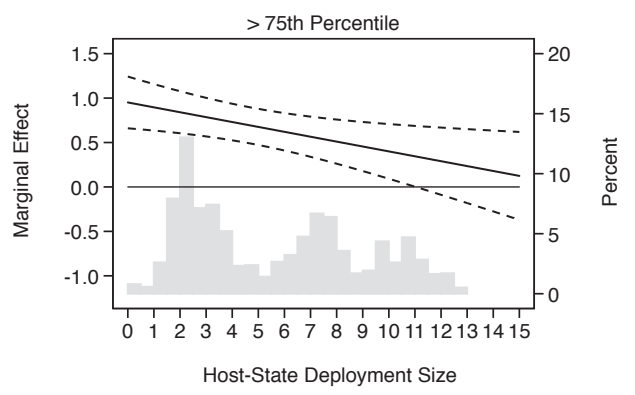

Figure A18: Marginal effect plot for pooled model and alliance sub-sample models. 95\% confidence intervals shown around coefficient point estimate. Panels show UN voting ideal point distance from the US in quartiles.

Table A9: US Troop Deployments and Host-State Defense Burdens. Models estimated using $\frac{1}{G D P}$ as the dependent variable.

\begin{tabular}{|c|c|c|c|c|c|c|c|c|}
\hline \multirow[b]{2}{*}{$\ln$ (Troops) } & \multicolumn{2}{|c|}{$\begin{array}{c}(1) \\
\text { All States }\end{array}$} & \multicolumn{2}{|c|}{$\begin{array}{c}(2) \\
\text { Non-NATO Allies }\end{array}$} & \multicolumn{2}{|c|}{$\begin{array}{c}(3) \\
\text { NATO Allies }\end{array}$} & \multicolumn{2}{|c|}{$\begin{array}{c}(4) \\
\text { Non-Allies }\end{array}$} \\
\hline & $-0.000^{* * *}$ & $(0.000)$ & $0.000^{*}$ & $(0.000)$ & 0.000 & $(0.000)$ & $-0.000^{* * *}$ & $(0.000)$ \\
\hline ln (Troops Spatial Mean) & $-0.000^{* * *}$ & $(0.000)$ & 0.000 & $(0.000)$ & 0.000 & $(0.000)$ & $-0.000^{* * *}$ & $(0.000)$ \\
\hline Troops $\times$ Troops Spatial Mean & $0.000^{* * *}$ & $(0.000)$ & -0.000 & $(0.000)$ & -0.000 & $(0.000)$ & $0.000^{* * *}$ & $(0.000)$ \\
\hline Spatial Lag & -0.000 & $(0.000)$ & 0.000 & $(0.000)$ & 0.000 & $(0.000)$ & -0.000 & $(0.000)$ \\
\hline Host-State Allies (Spatial Mean) & -0.000 & $(0.000)$ & -0.000 & $(0.000)$ & $0.000^{* *}$ & $(0.000)$ & -0.000 & $(0.000)$ \\
\hline US Allies (Spatial Mean) & $-0.000^{* * *}$ & $(0.000)$ & -0.000 & $(0.000)$ & $0.000^{* *}$ & $(0.000)$ & $-0.000^{* * *}$ & $(0.000)$ \\
\hline Polity & 0.000 & $(0.000)$ & $-0.000^{*}$ & $(0.000)$ & 0.000 & $(0.000)$ & -0.000 & $(0.000)$ \\
\hline Growth & -0.000 & $(0.000)$ & 0.000 & $(0.000)$ & -0.000 & $(0.000)$ & -0.000 & $(0.000)$ \\
\hline $\ln$ (Population) & $-0.000^{* * *}$ & $(0.000)$ & $-0.000^{* * *}$ & $(0.000)$ & $-0.000^{* * *}$ & $(0.000)$ & $-0.000^{* * *}$ & $(0.000)$ \\
\hline Infant Mortality Rate & $0.000^{* * *}$ & $(0.000)$ & $0.000^{*}$ & $(0.000)$ & $0.000^{* * *}$ & $(0.000)$ & $0.000^{* * *}$ & $(0.000)$ \\
\hline Interstate War & 0.000 & $(0.000)$ & 0.000 & $(0.000)$ & -0.000 & $(0.000)$ & 0.000 & $(0.000)$ \\
\hline Civil War & $0.000^{* * *}$ & $(0.000)$ & -0.000 & $(0.000)$ & 0.000 & $(0.000)$ & $0.000^{* * *}$ & $(0.000)$ \\
\hline MIDs & -0.000 & $(0.000)$ & -0.000 & $(0.000)$ & -0.000 & $(0.000)$ & -0.000 & $(0.000)$ \\
\hline Threat Environment & $-0.000^{* * *}$ & $(0.000)$ & $-0.000^{* *}$ & $(0.000)$ & -0.000 & $(0.000)$ & $-0.000^{* * *}$ & $(0.000)$ \\
\hline \# Border States & -0.000 & $(0.000)$ & $0.000^{* * *}$ & $(0.000)$ & 0.000 & $(0.000)$ & $-0.000^{*}$ & $(0.000)$ \\
\hline Constant & $0.000^{* * *}$ & $(0.000)$ & $0.000^{* * *}$ & $(0.000)$ & $0.000^{* * *}$ & $(0.000)$ & $0.000^{* * *}$ & $(0.000)$ \\
\hline$R^{2}$ & 0.173 & & 0.288 & & 0.475 & & 0.215 & \\
\hline Prob $>\chi^{2}$ & 0.000 & & 0.000 & & 0.621 & & 0.000 & \\
\hline Observations & 6179 & & 1311 & & 675 & & 4193 & \\
\hline
\end{tabular}

Panel-corrected standard errors in parentheses. Two-tailed significance tests used.

$* \mathrm{p} \leq 0.10 ; * * \mathrm{p} \leq 0.05 ; * * * \mathrm{p} \leq 0.01$ 
(1)

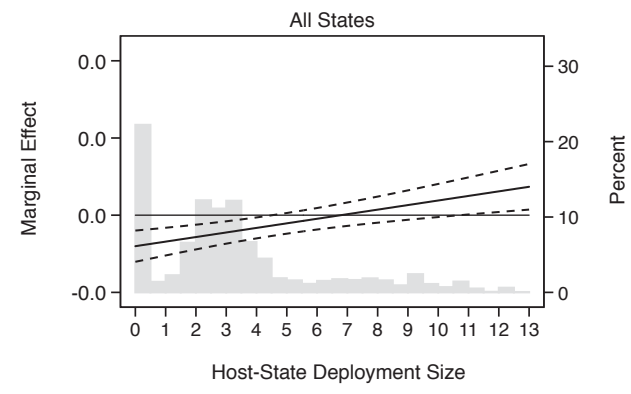

(3)

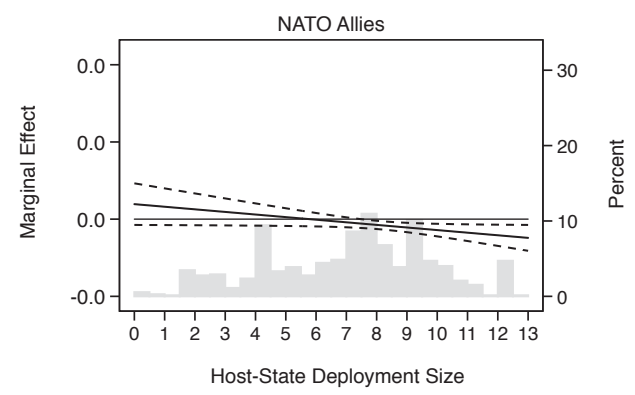

(2)

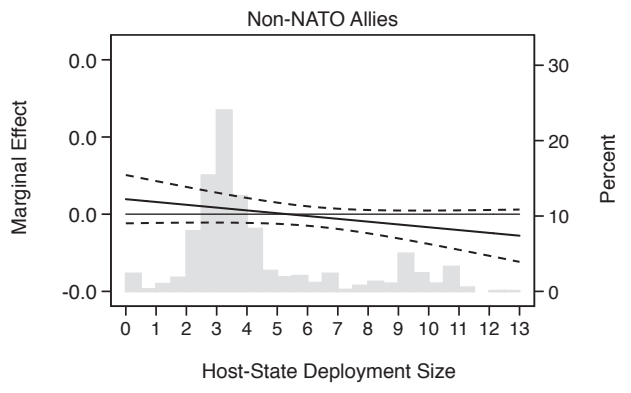

(4)

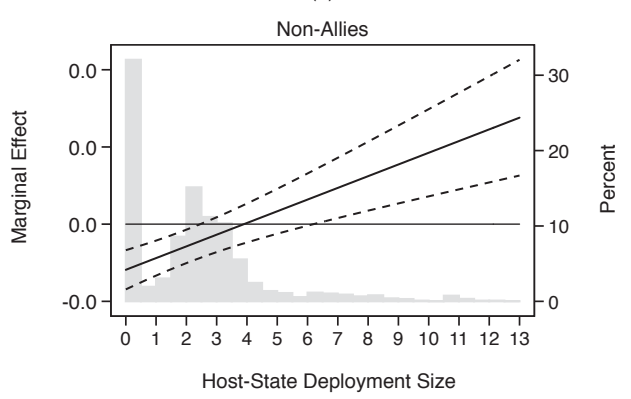

Figure A19: Marginal effect plot for pooled model and alliance sub-sample models using $\frac{1}{G D P}$ as the dependent variable. 95\% confidence intervals shown around coefficient point estimate.

Table A10: US Troop Deployments and Host-State Defense Burdens. Model 4 includes Warsaw Pact Membership Variable.

\begin{tabular}{lcccccccc}
\hline \hline & \multicolumn{2}{c}{$(1)$} & \multicolumn{2}{c}{$(2)$} & \multicolumn{2}{c}{$(3)$} & \multicolumn{2}{c}{$(4)$} \\
& \multicolumn{2}{c}{ All States } & Non-NATO Allies & NATO Allies & \multicolumn{2}{c}{ Non-Allies } \\
\hline ln (Troops) & 0.032 & $(0.098)$ & 0.022 & $(0.046)$ & -0.161 & $(0.129)$ & -0.149 & $(0.159)$ \\
In (Troops Spatial Mean) & $0.565^{* * *}$ & $(0.079)$ & 0.063 & $(0.044)$ & -0.099 & $(0.095)$ & $0.666^{* * *}$ & $(0.099)$ \\
Troops $\times$ Troops Spatial Mean & $-0.040^{* * *}$ & $(0.012)$ & -0.004 & $(0.008)$ & $0.027^{* *}$ & $(0.013)$ & -0.032 & $(0.021)$ \\
Spatial Lag & $17.957^{* * *}$ & $(2.901)$ & $0.894^{*}$ & $(0.534)$ & $9.444^{* * *}$ & $(3.019)$ & $26.104^{* * *}$ & $(3.796)$ \\
Host-State Allies (Spatial Mean) & $2.025^{* * *}$ & $(0.441)$ & -0.381 & $(0.435)$ & $0.596^{*}$ & $(0.338)$ & $2.299^{* * *}$ & $(0.530)$ \\
US Allies (Spatial Mean) & $-1.965^{* * *}$ & $(0.476)$ & -0.027 & $(0.558)$ & $0.591^{* *}$ & $(0.290)$ & $-2.269^{* * *}$ & $(0.837)$ \\
Polity & $-0.091^{* * *}$ & $(0.013)$ & $-0.018^{* * *}$ & $(0.006)$ & $-0.031^{*}$ & $(0.016)$ & $-0.126^{* * *}$ & $(0.019)$ \\
Growth & -0.005 & $(0.007)$ & -0.001 & $(0.003)$ & 0.000 & $(0.005)$ & -0.005 & $(0.008)$ \\
ln (Population) & -0.071 & $(0.139)$ & -0.081 & $(0.098)$ & $0.321^{* * *}$ & $(0.072)$ & -0.058 & $(0.161)$ \\
Infant Mortality Rate & $-0.007^{*}$ & $(0.004)$ & -0.001 & $(0.001)$ & $0.007^{*}$ & $(0.003)$ & $-0.009^{*}$ & $(0.005)$ \\
Interstate War & $1.394^{* * *}$ & $(0.319)$ & $0.259^{*}$ & $(0.143)$ & 0.166 & $(0.104)$ & $2.269^{* * *}$ & $(0.527)$ \\
Civil War & $0.681^{* *}$ & $(0.287)$ & 0.000 & $(0.075)$ & 0.101 & $(0.115)$ & $0.856^{* *}$ & $(0.372)$ \\
MIDs & 0.131 & $(0.127)$ & $0.134^{*}$ & $(0.073)$ & 0.012 & $(0.053)$ & 0.185 & $(0.160)$ \\
Threat Environment & $-3.301^{* * *}$ & $(0.834)$ & $-1.027^{*}$ & $(0.532)$ & -0.949 & $(0.650)$ & $-2.937^{* *}$ & $(1.283)$ \\
Warsaw Pact Member & & & & & & & 0.144 & $(0.650)$ \\
\# Border States & $0.140^{*}$ & $(0.080)$ & 0.041 & $(0.049)$ & -0.016 & $(0.034)$ & 0.075 & $(0.100)$ \\
Constant & 1.644 & $(1.379)$ & $2.411^{* *}$ & $(0.998)$ & -0.419 & $(1.295)$ & 1.160 & $(1.643)$ \\
\hline$R^{2}$ & 0.084 & & 0.104 & & 0.292 & & 0.106 & 0.000 \\
Prob > $\chi^{2}$ & 0.000 & & 0.000 & & 0.000 & & & 4058 \\
Observations & 6052 & & 1273 & & 721 & & &
\end{tabular}

Panel-corrected standard errors in parentheses. Two-tailed significance tests used.

$* \mathrm{p} \leq 0.10 ; * * \mathrm{p} \leq 0.05 ; * * * \mathrm{p} \leq 0.01$ 
(1)

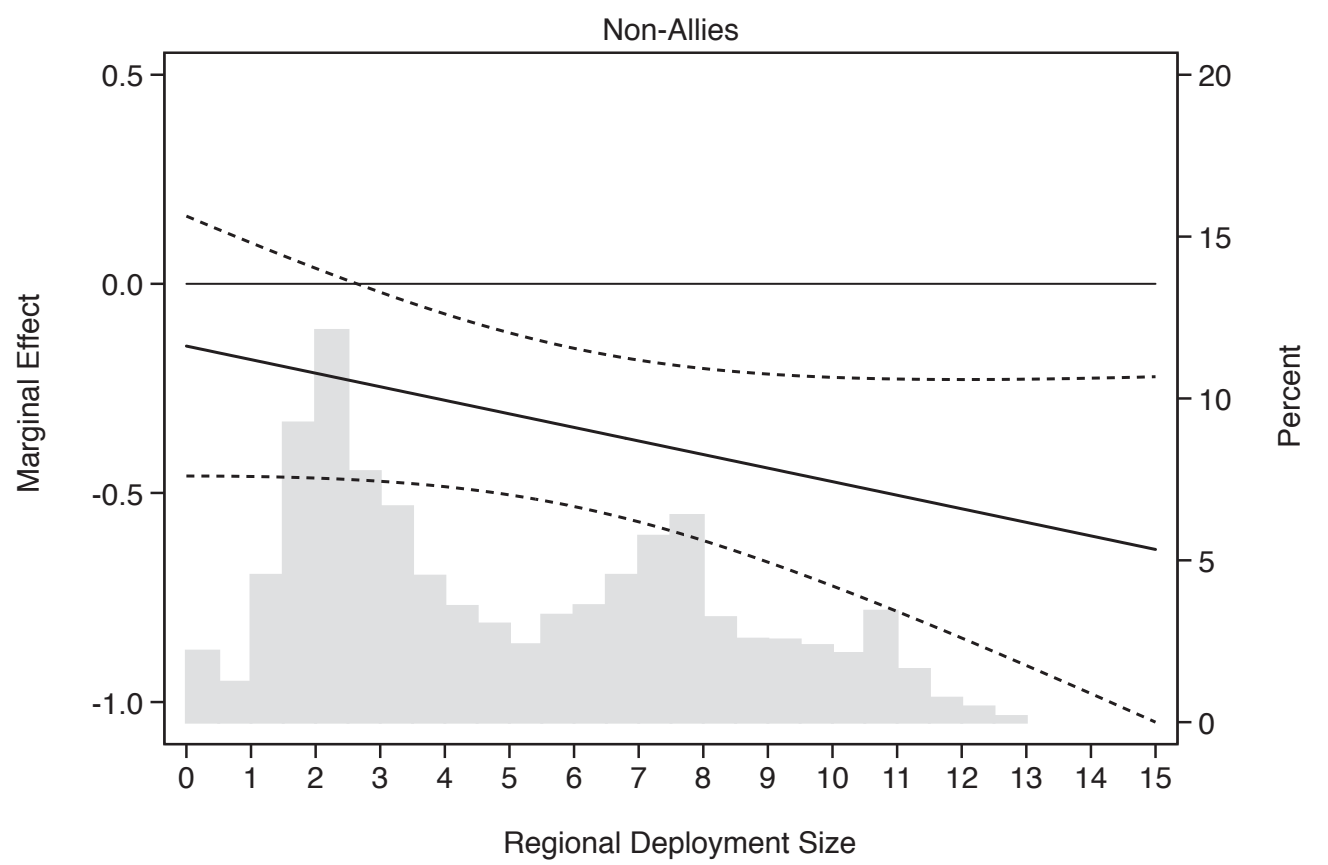

Figure A20: Marginal effect for increase in host-state troop deployments for non-allies of the US. Model includes Warsaw Pact dummy variable. 
(1)

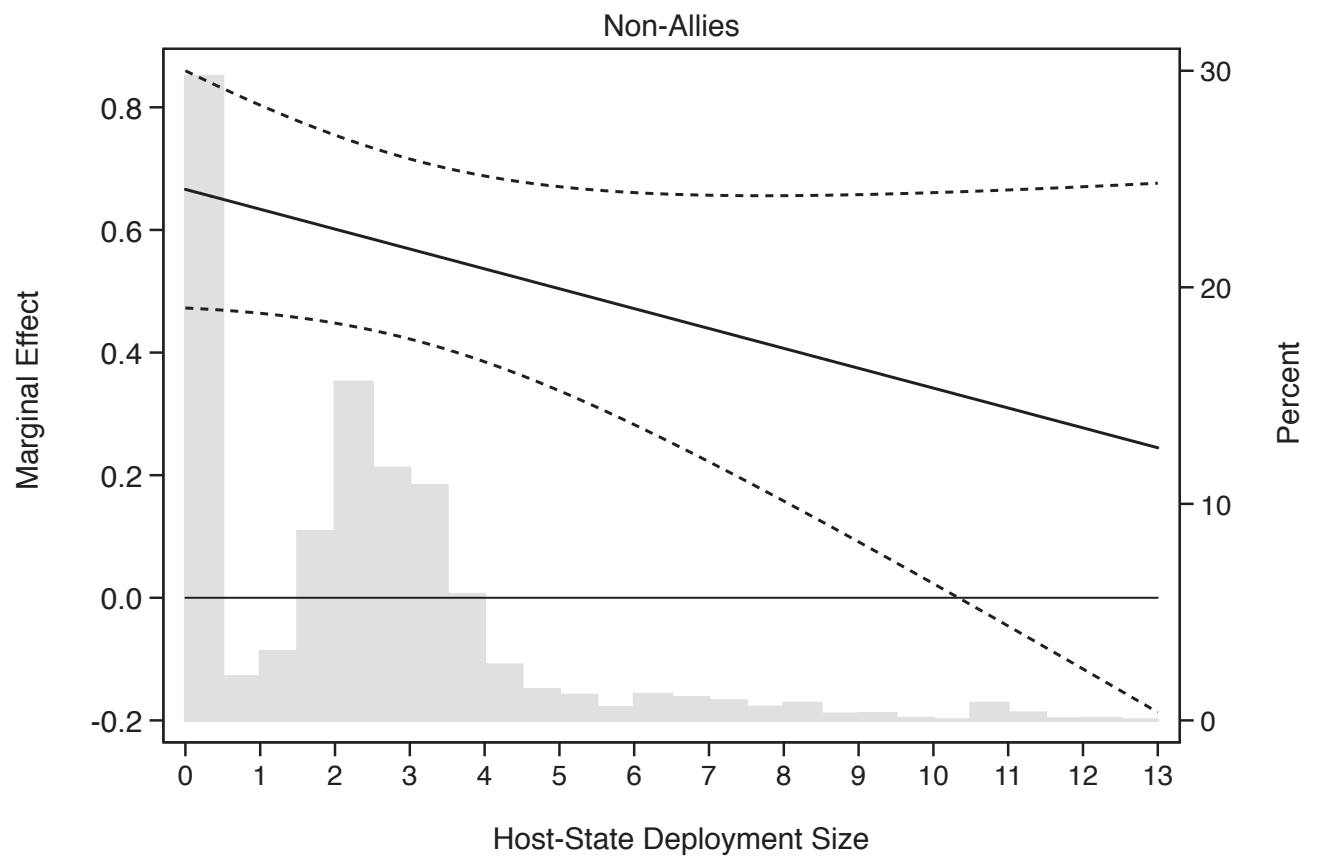

Figure A21: Marginal effect for increase in regional troop deployments for non-allies of the US. Model includes Warsaw Pact dummy variable.

Table A11: Model Comparison Table

\begin{tabular}{lcc}
\hline \hline Sample & Base RSS & Full RSS \\
\hline All States & $2.97 \mathrm{e}+04$ & $2.92 \mathrm{e}+04$ \\
Non-NATO Allies & 248.3130 & 248.0996 \\
NATO Allies & 101.1777 & 116.8594 \\
Non-Allies & $2.72 \mathrm{e}+04$ & $2.67 \mathrm{e}+04$ \\
\hline \hline
\end{tabular}




\section{References}

Abouharb, M. Rodwan and Anessa L. Kimball. 2007. "A new dataset on infant mortality rates, 1816-2002." Journal of Peace Research 44(6):743-754.

Allen, Micahel A. and Matthew Digiuseppe. 2013. "Tightening the belt: Sovereign Debt and Alliance Formation." International Studies Quarterly 57(4):647-659.

Bremer, Stuart A. 1992. "Dangeours dyads: Conditions affecting the likelihood of interstate war." Journal of Conflict Resolution 36(2):309-341.

Fordham, Benjamin O. and Thomas C. Walker. 2005. "Kantian liberalism, regime type, and military resource allocation: Do democracies spend less?" International Studies Quarterly 49(1):141-157.

Ghosn, Faten, Glenn Palmer and Stuary Bremer. 2004. "The MID3 data set, 1993-2001: Procedures, coding rules, and description." Conflict Management and Peace Science 21:133154.

Gleditsch, Kristian Skrede. 2002. "Expanded trade and GDP data." Journal of Conflict Resolution 46(5):712-724.

Kimball, Anessa L. 2010. "Political survival, policy distribution, and allianceformation." Journal of Peace Research 47(4):407-419.

Leeds, B.A. and B. Savun. 2007. "Terminating alliances: Why do states abrogate agreements?" Journal of Politics 69(4):1118-1132.

Marshall, Monty G., Keith Jaggers and Ted Robert Gurr. 2011. "Polity IV project:Ppolitical regime characteristics and transitions, 1800-2010.".

Sarkees, Meredeith Reid and Frank Wayman. 2010. Resort to war: 1816-200\%. Washington, D.C.: CQ Press.

Signorino, Curtis S. and Jeffrey M. Ritter. 1999. "Tau-b or Not Tau-b: Measuring the Similarity of Foreign Policy Positions." International Studies Quarterly 43(1):115-144.

Singer, J. David. 1987. "Reconstructing the Correlates of War dataset on material capabilities of states, 1816-1985." International Interactions 14:115-132.

Stinnett, Douglas M., Jaroslav Tir, Philip Schafer, Paul F. Diehl and Charles Gochman. 2002. "The correlates of war project direct contiguity data, version 3." Conflict Management and Peace Science 19(2):58-66.

Sweeney, Kevin and Omar M. G. Keshk. 2005. "The Similarity of States: Using S to Compute Dyadic Interest Similarity." Conflict Management and Peace Science 22(2):165-187. 